
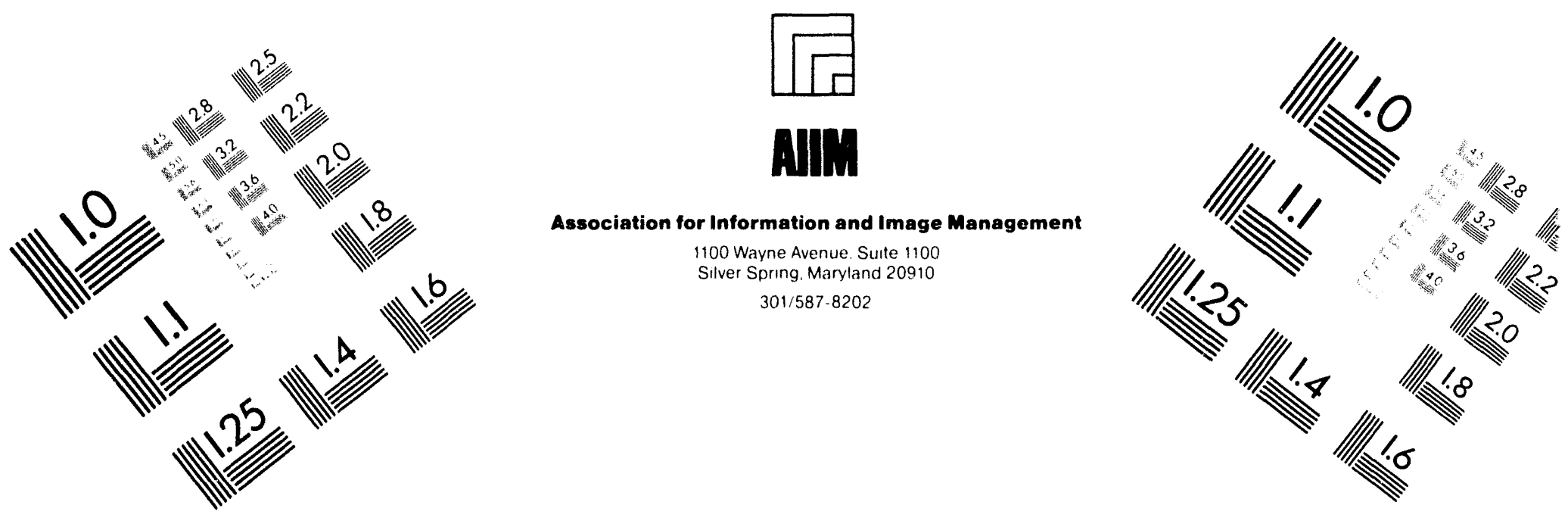

\title{
Centimeter
}

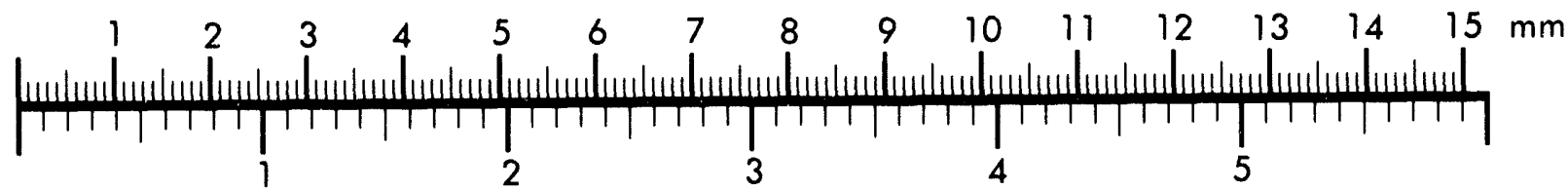
Inches
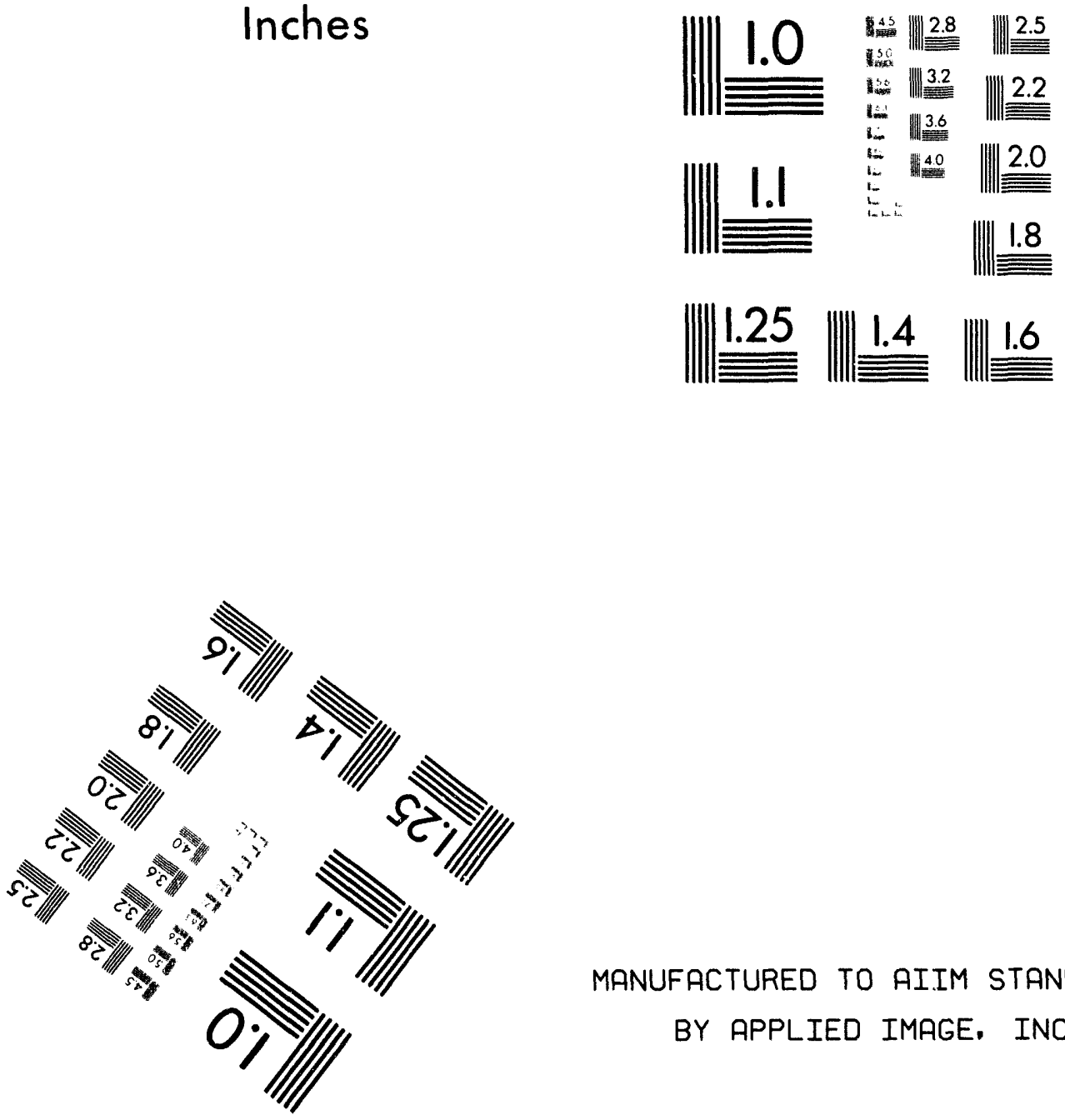

MANUFACTURED TO AIIM STANDARDS BY APPLIED IMAGE. INC.

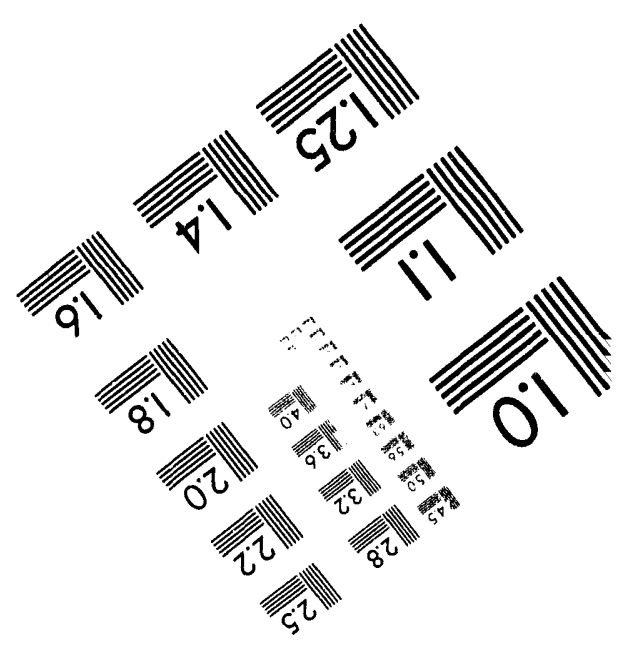



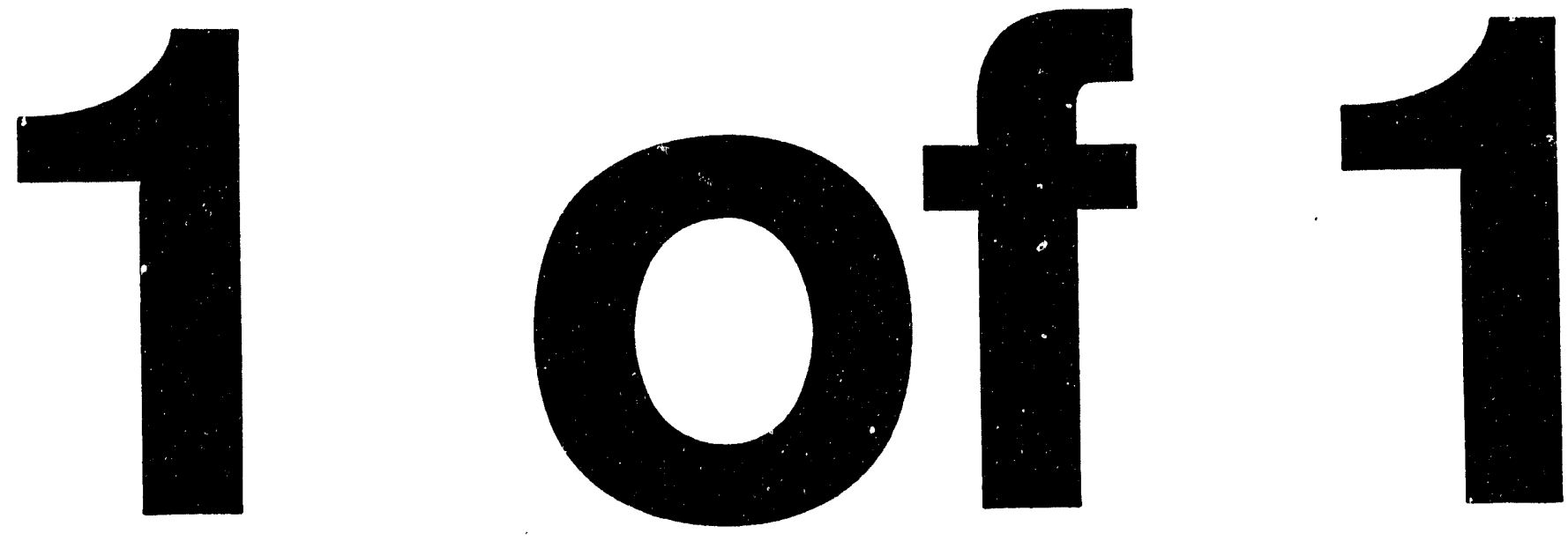


\section{WHITE PAPER: \\ MULTHPURPOSE CANISTER (MPC) \\ FOR DOE-OWNED SPENT NUCLEAR FUEL (SNF)}

D. A. Knecht

April 1994

\section{Westinghouse Idaho}

PREPARED FOR THE

DEPARTMENT OF ENERGY IDAHO OPERATIONS OFFICE

UNDER CONTRACT DE-AC07-84ID12435

$$
\text { MASTRP }
$$




\begin{abstract}
The White Paper, Multi-Purposed Canister (MPC) for DOE-Owned Spent Nuclear Fuel (SNF) examines the issue, "What are the advantages, disadvantages, and other considerations for using the MPC concept as part of the strategy for interim storage and disposal of DOE-owned SNF?" The Paper is based in part on the results of an evaluation made for the DOE National Spent Fuel Program by the Waste Form Barrier/Canister Team, which is composed of knowledgeable DOE and DOE-contractor personnel. The Paper reviews the MPC and DOE SNF status, provides criteria and other considerations applicable to the issue, and presents an evaluation, conclusions, and recommendations. The primary conclusion is that while most of DOE SNF is not currently sufficiently characterized to be sealed into an MPC, the advantages of standardized packages in handling, reduced radiation exposure, and improved human factors should be considered in DOE SNF program planning. While the design of MPCs for DOE SNF are likely premature at this time, the use of canisters should be considered which are consistent with interim storage options and the MPC design envelope.
\end{abstract}




\section{TABLE OF CONTENTS}

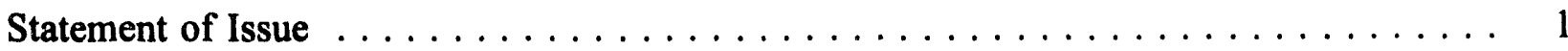

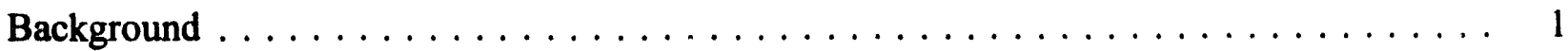

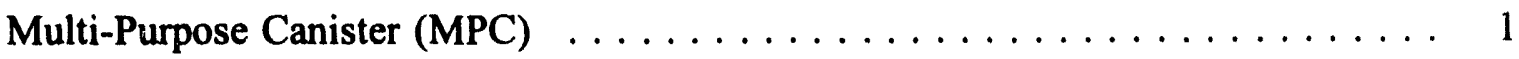

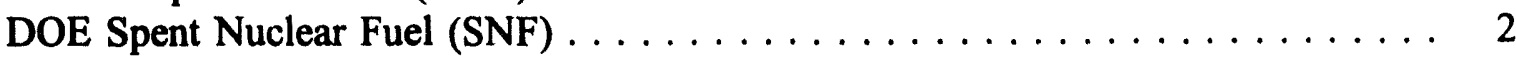

DOE SNF Environmental Safety and Health (ES\&H) Vulnerability Assessment . . . . . . 3

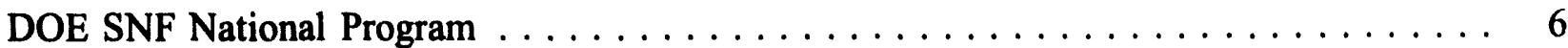

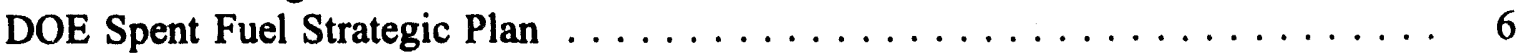

DOE Spent Fuel Interim Storage Plan Issues $\ldots \ldots \ldots \ldots \ldots \ldots$

Team Criteria and Related Considerations for the

Evaluation of Use of an MPC for DOE SNF $\ldots \ldots \ldots \ldots \ldots \ldots$

Fuel Durability, Dimensions, and Composition $\ldots \ldots \ldots \ldots \ldots$

Potential for Designation as a Hazardous Waste $\ldots \ldots \ldots \ldots \ldots \ldots$

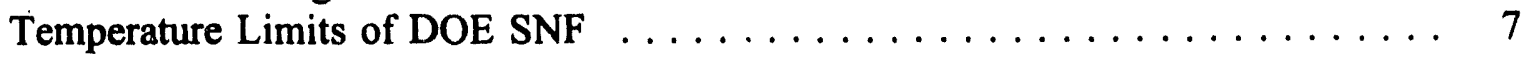

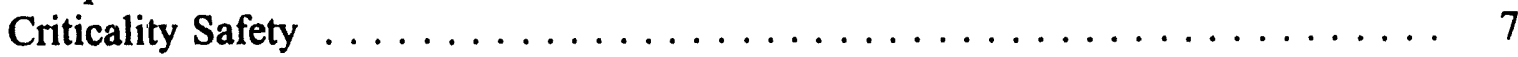

Special Nuclear Materials (SNM) Protection - Safeguards and Accountability . . . 8

Repository Waste Package Design Requirements (10 CFR 60.135) . . . . . . . . . 8

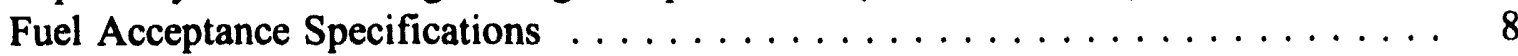

Degree of Similarity of DOE Fuels with Commercial Fuel Storage/Disposal . . . . 9

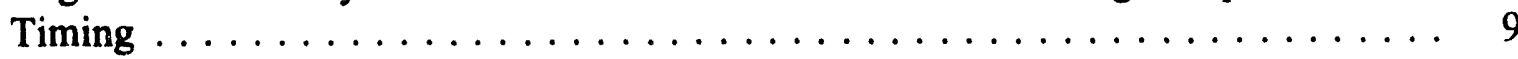

Segregation of DOE SNF Categories $\ldots \ldots \ldots \ldots \ldots \ldots \ldots$

Other Programmatic Issues Impacting Repository Disposal . . . . . . . . . . . . 9

Evaluation of MPC Use for DOE SNF $\ldots \ldots \ldots \ldots \ldots \ldots$

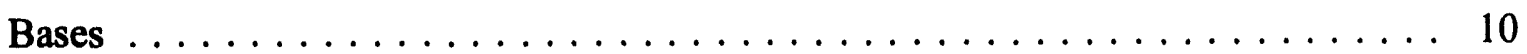

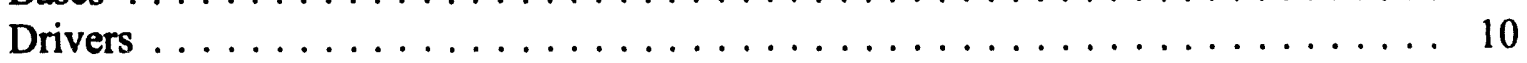

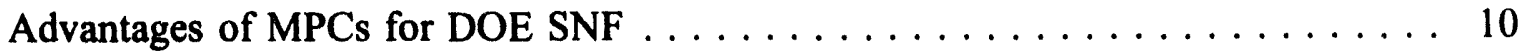

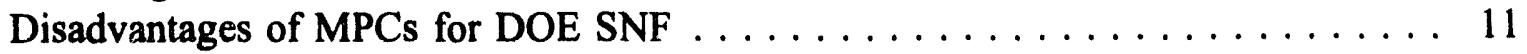

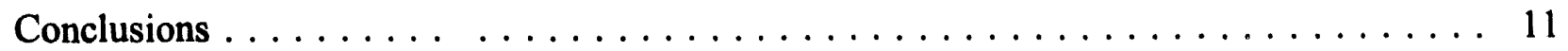

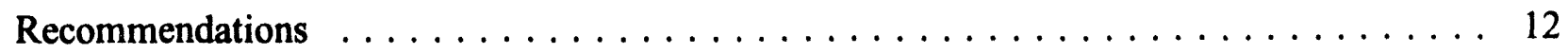

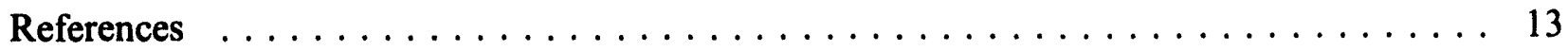


APPENDIX A. LIST OF ATTENDEES OF 2/23/94 TEAM MEETING

AND WASTE FORM BARRIER/CANISTER TEAM MEMBERS . . . . A-1

APPENDIX B. DETAILED DESCRIPTION OF DOE SNF

CHARACTERISTICS AND QUANTITIES $\ldots \ldots \ldots \ldots \ldots \ldots \ldots$ B-1

APPENDIX C. APPLICATION OF MPCS TO EACH DOE SNF CATEGORY $\ldots \ldots \ldots$ C-1

\section{FIGURES}

Figure 1. Distribution of DOE SNF throughout all DOE Sites. Comparison based on mass, volume, number of storage units, $U$ mass, mass of fissile material, and mass of heavy metal $\ldots \ldots \ldots \ldots \ldots \ldots \ldots, 5$

\section{TABLES}

Table 1. Summary Characteristics of DOE SNF $\ldots \ldots \ldots \ldots \ldots \ldots \ldots$

Table C-1. Evaluation by Criteria of MPC for Each DOE SNF Category.

Rating of Each Criterion to an MPC is (H) High Acceptability, (M)

Medium Acceptability, (L) Low Acceptability . . . . . . . . . . . C-2 


\section{Statement of Issue}

This White Paper examines the issue: "What are the advantages, disadvantages and other considerations of using the multi-purpose canister (MPC) concept as part of the strategy for interim storage and disposal of DOE-owned spent nuclear fuel (SNF)?" An evaluation of this issue was made for the DOE SNF National Program by the Waste Form Barrier/Canister Team composed of knowledgeable DOE and DOE-contractor personnel (see Appendix A for list of members), and the results, conclusions and recommendations are presented herein.

\section{Background}

The Department of Energy Office of Civilian Radioactive Waste Management (DOEOCRWM) is evaluating the use of an MPC for the interim storage, transportation, and disposal of commercial spent nuclear fuel, ${ }^{1}$ and, according to a 2/24/94 DOE news release, Secretary O'Leary "has directed OCRWM to proceed with the next phase of the development program for ... MPCs, including the acquisition of designs for submission to the ... Nuclear Regulatory Commission (NRC) for certification and appropriate environmental review." Following the change in DOE mission to terminate reprocessing of DOE-owned SNF, DOE is developing a program for management of the DOE-owned SNF for interim storage and ultimate disposal with emphasis on using as much commercial technology as possible. Because DOE SNF is quite varied in composition and characteristics, and generally significantly different from commercial SNF, additional characterization and conditioning may be required before disposal. In addition, an immediate need to solve current storage vulnerabilities has been identified by DOE Spent Fuel Working Group. ${ }^{2}$ The resulting actions which may be required to solve storage vulnerabilities could result in placement of some of the SNF into interim dry storage before adequate characterization and detailed repository acceptance criteria have been established. This White Paper considers the MPC and DOE SNF characteristics and special needs in an evaluation of the use of an MPC for interim storage, transportation and disposal of DOE SNF.

Multi-Purpose Canister (MPC). As described in a January, 1994, brochure issued by DOE Office of Civilian Radioactive Waste Management (OCRWM), "A multi-purpose canister is a metal container holding spent fuel... Together with appropriate outer containers, or overpacks, it would be used for temporary storage at reactor sites, transportation from reactor sites to the Monitored Retrieval Storage (MRS) facility, temporary storage at the MRS facility, transportation to the repository, and disposal in the repository."1 The MPC would be designed to provide dry storage, containment, acceptable fuel cladding temperatures, high strength and subcriticality during storage, transportation, and disposal. The MPC concept assumes that it is welded shut and does not have to be opened, which results in advantages, including minimized handling of individual SNF assemblies and compatibility between the dry storage devices used at storage sites and DOE facilities.' The storage of MPCs at the reactor will require licensing of the utility under 10 CFR 72 by the NRC. Transportation of the MPC and cask must be certified by the NRC under 10 CFR 71, including a demonstration that the MPC-cask system can withstand hypothetical accident conditions without losing integrity, releasing excessive radioactive materials, or experiencing a criticality. The MPC disposal at the repository will be licensed by the NRC under 10 CFR 60, which includes specifications on the long-term performance of the waste package. The waste package is the 
engineered barrier to the release of radionuclides and consists of the waste or SNF, the outer disposal container, or overpack, and an internal container such as the MPC. Thus, the MPC does not have to meet the 300-1000 yr containment requirements of 10 CFR 60.113 by itself, but must be compatible with the highly durable outer disposal overpack to be developed after the repository has been characterized. As part of the schedule for development of the MPC, a Request for Proposal (RFP), including performance specifications, will be issued by DOEOCRWM in May, 1994.

A conceptual design has recently been issued by DOE-OCRWM and includes the conceptual design of the various components, draft requests for the proposal and design specifications, and results of supporting studies. ${ }^{3}$ A feasibility study was issued in which preconceptual MPC designs were completed for the DOE SNF types of N-Reactor, aluminum Advanced Test Reactor (ATR) and Materials Test Reactor (MTR), Three Mile Island (TMI) commercial fuel canisters, and Fort St. Vrain graphite block assemblies. ${ }^{4}$ Some of the key points of the DOE-OCRWM conceptual design are described in the following: ${ }^{3}$

Two sizes of the MPC under consideration are a large canister with a capacity of 21 pressurized water reactor (PWR) or 40 boiling water reactor (BWR) assemblies which would weigh nominally 125 tons, including the transport cask, and an intermediate canister with a capacity of 12 PWR or 24 BWR assemblies with a nominal weight of 75 tons, including the cask. A 25-ton transport cask would be used to move fuel from reactors which have access by truck but not by rail for transportation to a facility, such as an MRS, for reloading the fuel into one of the MPCs. The 125-ton MPC concept is only compatible with a high heat-loading strategy at the repository and requires an assumption of burn-up credit for PWR fuel to meet the sub-criticality specifications, otherwise the 75-ton MPC must be used. The conceptual maximum temperature of commercial-fuel zircaloy cladding (10-yr cooled for 20-yr storage) is limited to $340^{\circ} \mathrm{C}$ by using aluminum sheets to conduct and remove the excess heat. Criticality is controlled by using borated aluminum or stainless-steel alloy in the MPC fuel basket. ${ }^{3}$

An alternative concept, which was also investigated in the conceptual design to provide a basis for evaluating the MPC, includes the transportable storage cask (TSC) system. The TSC is a container which satisfies the interim storage and transportation functions of an MPC, but not the disposal function. Such a dual function concept may be required for some of the DOE SNF in which more uncertainties exist concerning the need for additional stabilization or characterization before disposal. ${ }^{3}$

DOE Spent Nuclear Fuel (SNF). The DOE owns and is currently storing approximately 4506 metric tons total mass or 2675 metric tons mass of heavy metal (MTHM) of SNF and other reactor irradiated nuclear materials, herein referred to as DOE SNF. The SNF includes the following: a variety of reactor irradiated target materials for production of plutonium; fuels irradiated in commercial power reactors with title transferred to DOE for further testing; fuel irradiated for production of plutoniurn within the fuel itself (Hanford N-Reactor, Single Pass reactor); driver fuel irradiated in reactors containing special targets for isotope production (Savannah River Site (SRS) reactors); fuel irradiated in several types of research and experimental reactors (High Flux Isotope Reactor at Oak Ridge - HFIR, High Flux Beam Reactor at Brookhaven - HFBR, Fast Flux Test Facility at Hanford - FFTF, Advanced Test 
Reactor (ATR) and Naval Reactors ship propulsion program at Idaho and others as described in Table 1 and Appendix B.

DOE SNF is made up of over 100 fuel types with a wide range of characteristics, including both low and high enrichment of U-235, high Pu-239 content, metallic and oxide composition, and cladding of zircaloy, aluminum, stainless steel, graphite, and other metal alloys. Table 1 provides an overall summary of selected characteristics of DOE SNF as grouped into eight different categories, and Appendix B gives a more detailed listing. The quantities ${ }^{5}$ of SNF in Appendix B and Table 1 are projected for June 1, 1995, the date of the final Environmental Impact Statement (EIS), and are based on the current data base. Each category has a large variety of fuel types, in contrast with the small variety of commercial fuels.

Most DOE SNF is stored at DOE sites, including Hanford for primarily production reactor irradiated materials (approximately $80 \%$ of total mass of initial heavy metal-IHM); Idaho for naval reactor, commercial, and research reactor fuel (approximately $11 \%$ of IHM); and Savannah River for production reactor fuel and targets, commercial fuel, and research reactor fuel (approximately 7\% of IHM). Other sites, including West Valley for commercial fuel, store approximately $2 \%$ of IHM of DOE fuels. Figure 1 shows graphically the distribution of DOE fuels for different bases, including total mass, volume, number of storage units, uranium mass, fissile mass, and initial heavy metal mass.

The DOE Order 5820.2A is being revised to include DOE SNF management. The order will include details on some of the issues described in this White Paper, including fuel characterization.

\section{DOE SNF Environmental Safety and Health (ES\&H) Vulnerability Assessment}

The Spent Fuel Working Group was formed by DOE Office of Environmental Health and Safety (EH) in September, 1993, to provide an itemized inventory of spent fuel and other reactor irradiated nuclear materials and an initial assessment of the ES\&H vulnerabilities associated with the current storage and handling of these materials. After a series of meetings and assessments, the Spent Fuel Working Group Report ${ }^{2}$ was issued, and five fuel storage facilities were identified that warrant priority management attention to avoid unnecessary increase in worker radiation exposure and cost during clean up. These are the Hanford 105-K East Basin, Idaho Chemical Processing Plant (ICPP) 603 Underwater Fuel Storage Facility, Savannah River L- and K-Reactor Disassembly Basins, and Hanford PUREX Canyon. A draft Phase I action plan has been issued to address the vulnerabilities at these facilities and will likely involve removal of spent fuel into dry storage as soon as possible, generally by 2002, with a minimal amount of fuel characterization. ${ }^{6}$ Phase II and III reports are expected to be issued in April and September, 1994, respectively, at which time the following policy issues are expected to be resolved: ${ }^{6}$ a) path forward for geologic disposal of SNF, b) licensing of new interim storage by NRC, c) storage of Hanford N-Reactor fuel in a dry configuration, and d) contingency plans if some DOE SiNF is deemed unsuitable for extended interim, dry storage or direct geologic disposal. 
Table 1. Summary Characteristics of DOE SNF

\begin{tabular}{|c|c|c|c|c|c|}
\hline Type & Fuel Material & Cladding & Enrichment & Burnup & MTHM" \\
\hline 1. Naval & Classified & $\mathrm{Zr}$ & high & Classified & 9.9 \\
\hline $\begin{array}{l}2 . \\
\text { Aluminum- } \\
\text { clad }\end{array}$ & $\begin{array}{l}\mathrm{UAl}_{\mathrm{x}} \\
\mathrm{UAl}_{\mathrm{x}} \\
\mathrm{U} \text { metal } \\
\mathrm{UO}_{2}\end{array}$ & $\begin{array}{l}\mathrm{Al} \\
\mathrm{Al} \\
\mathrm{Al} \\
\mathrm{Al}\end{array}$ & $\begin{array}{l}\text { high } \\
\text { high } \\
\text { depleted } \\
\text { high }\end{array}$ & $\begin{array}{l}\text { low } \\
\text { high } \\
\text { high } \\
\text { high }\end{array}$ & $\begin{array}{r}17.7 \\
33.7 \\
138.2 \\
0.6 \\
190.2 \\
\text { Sub-Total } \\
\end{array}$ \\
\hline $\begin{array}{l}\text { 3. Hanford } \\
\text { Production }\end{array}$ & $\begin{array}{l}\text { U metal } \\
\text { U metal }\end{array}$ & $\begin{array}{l}\mathrm{Zr} \\
\mathrm{Al}\end{array}$ & $\begin{array}{l}\text { low } \\
\text { low }\end{array}$ & $\begin{array}{l}\text { low } \\
\text { low }\end{array}$ & \begin{tabular}{|c}
2100 \\
3.4 \\
2103.4 \\
Sub-Total \\
\end{tabular} \\
\hline 4. Graphite & U carbide & $\begin{array}{l}\text { Si carbide } \\
\text { Graphite }\end{array}$ & high & medium & Qub-Total \\
\hline $\begin{array}{l}5 . \\
\text { Commercial }\end{array}$ & $\begin{array}{l}\mathrm{UO}_{2} \text {-Intact } \\
\mathrm{UO}_{2} \text {-Damaged } \\
\text { Other }\end{array}$ & $\begin{array}{l}\mathrm{Zr} \\
\mathrm{Zr} \\
\mathrm{SS}\end{array}$ & $\begin{array}{l}\text { low } \\
\text { low } \\
\text { low }\end{array}$ & $\begin{array}{l}\text { high } \\
\text { high } \\
\text { high }\end{array}$ & \begin{tabular}{|c|}
74.3 \\
82 \\
2.5 \\
158.8 \\
Sub-Total \\
\end{tabular} \\
\hline $\begin{array}{l}\text { 6a. } \\
\text { SS Test }\end{array}$ & $\begin{array}{l}\mathrm{U} \text { metal } \\
\mathrm{PuO}_{2} \\
\mathrm{UO}_{2} \text { or alloy } \\
\text { Other } \\
\text { Other }\end{array}$ & $\begin{array}{l}\text { SS } \\
\text { SS } \\
\text { SS } \\
\text { SS } \\
\text { SS }\end{array}$ & $\begin{array}{l}\text { high } \\
\text { high } \\
\text { low } \\
\text { high } \\
\text { low }\end{array}$ & $\begin{array}{l}\text { high } \\
\text { high } \\
\text { high } \\
\text { various } \\
\text { various }\end{array}$ & \begin{tabular}{|c}
48.4 \\
9.5 \\
47.9 \\
0.09 \\
1.05 \\
106.9 \\
Sub-Total \\
\end{tabular} \\
\hline $\begin{array}{l}\text { 6b. } \\
\mathrm{Zr} \text { Test }\end{array}$ & $\begin{array}{l}\text { U-Mo alloy } \\
\mathrm{UO}_{2} \\
\mathrm{UO}_{2} \\
\text { Other }\end{array}$ & $\begin{array}{l}\mathrm{Zr} \\
\mathrm{Zr} \\
\mathrm{Zr} \\
\mathrm{Zr}\end{array}$ & $\begin{array}{l}\text { high } \\
\text { low } \\
\text { low } \\
\text { high }\end{array}$ & $\begin{array}{l}\text { low } \\
\text { unknown } \\
\text { high } \\
\text { various }\end{array}$ & \begin{tabular}{|c}
4 \\
43 \\
18 \\
12 \\
77.0 \\
Sub-Total \\
\end{tabular} \\
\hline 6c. Other & U-F salts & none & low & low & \begin{tabular}{|c}
0.04 \\
Sub-Total
\end{tabular} \\
\hline
\end{tabular}

- Projected to June 1, 1995, the proposed issue date of the DOE SNF EIS. 

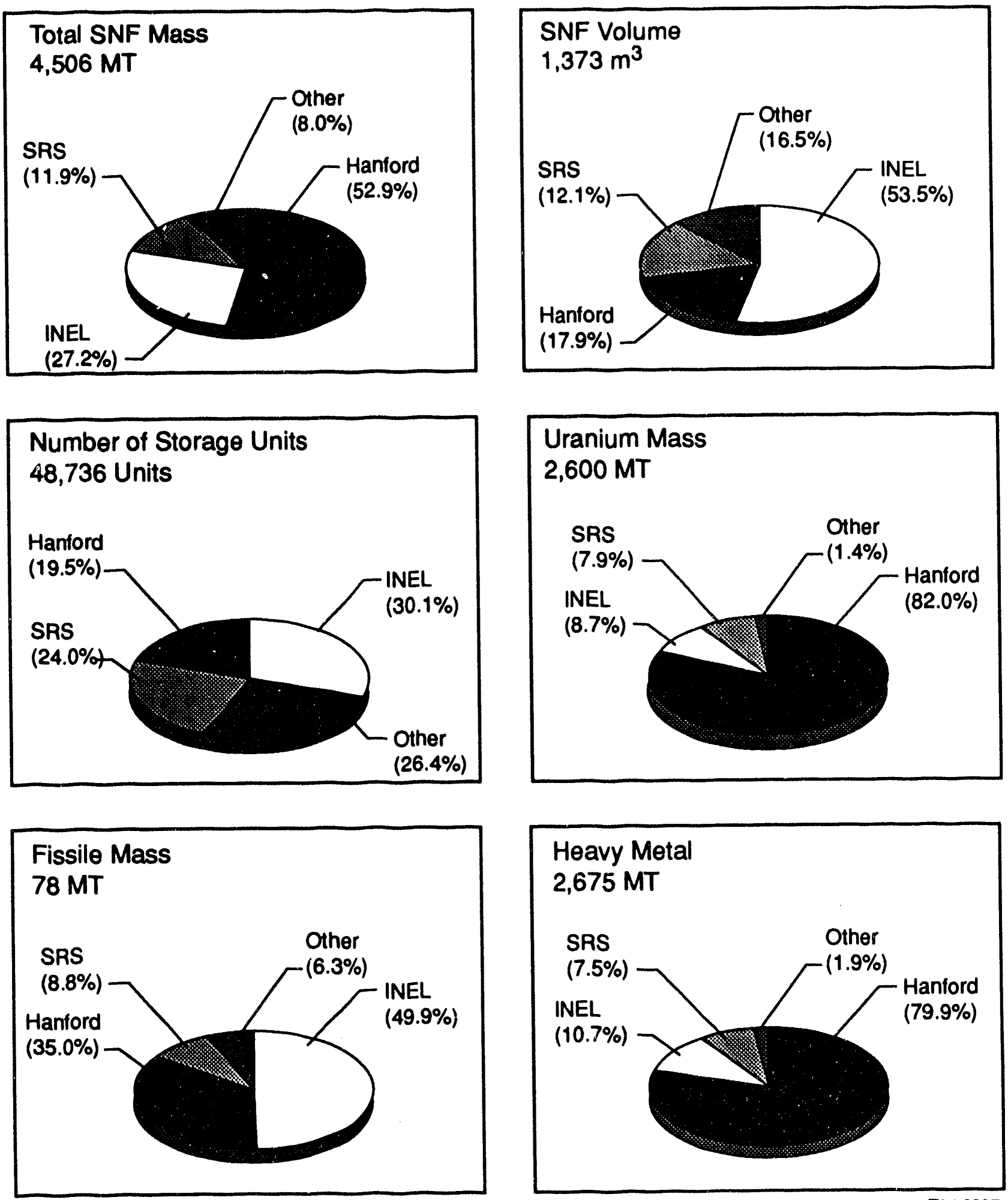

MT - Metric tons $(1000 \mathrm{~kg}$ or $2,205 \mathrm{lb})$

INEL - Defined here as the physical location and includes DOE-ID facilities, NRF and ANL-W

Other - Includes other DOE sites, non-DOE domestic reactor fuel, and research reactor fuel that will be owned and managed by $D O E$

Figure 1. Distribution of DOE SNF throughout all DOE Sites. Comparison based on mass, volume, number of storage units, $U$ mass, mass of fissile material, and mass of heavy metal 


\section{DOE SNF National Program}

The DOE SNF National Program has been set up under DOE Office of Environmental Management (EM) EM-37 to coordinate the assessment and dispositioning of all DOE SNF. Major activities to date include an SNF Strategic Plan, an SNF Database, an assessment of facilities, and a development of an Interim Storage Plan, Characterization Plan and Technology Integration Plan. A Systems Engineering program is being undertaken to develop a comprehensive schedule of work required for the duration of the DOE SNF program.

DOE Spent Fuel Strategic Plan. A draft Strategic Plan has been developed, which recommends the following:

- $\quad$ Place SNF in 40-year safe interim storage as soon as possible

- Shut down inadequate existing storage facilities

- Minimize immediate characterization to support only dry storage needs

- Complete necessary characterization prior to disposal

- Condition the SNF for disposal based on the repository waste acceptance criteria

- $\quad$ Place SNF eventually in the first geologic repository

DOE Spent Fuel Interim Storage Plan Issues. Preparation of an Interim Storage Plan has been started with the goal to achieve safe, cost-effective interim storage of all DOE SNF pending repository disposal. Topics which will be addressed include the consolidation of DOE fuel storage locations, fuel conditioning strategies, facility upgrades and replacements, transportation, schedules and cost estimates. Some of the technical issues which have been identified include dry vs wet storage, conditioning requirements, storage condition envelope, storage of degraded fuel, location of storage facilities, fuel shipments, and interface and consistency with DOE-OCRWM fuel storage, transportation and disposal. A draft report describes technical issues for possible dry storage of DOE-owned fuel. ${ }^{7}$ Recently, DOE EM37 has announced the possibility of constructing new interim storage facilities under NRC licensing oversight, ${ }^{8}$ which may also help to meet waste acceptance requirements for disposal in a repository.

Team Criteria and Related Considerations for the Evaluation of Use of an MPC for DOE SNF

The Waste Form Parrier/Canister Team met in Idaho Falls on February 23, 1994. The objective of this Team meeting was to review existing DOE SNF information and provide a preliminary assessment whether or not the MPC should be included as part of the strategy for interim storage and eventual disposal. The list of Team members and meeting attendees is shown in Appendix A. 
The Team developed criteria which were considered to be important for the use of an MPC for the storage, transportation, and disposal of DOE SNF. The criteria and related considerations include fuel durability, hazardous waste potential, temperature limits, criticality safety, special nuclear materials (SNM) issues, waste package design requirements, fuel acceptance specifications, similarity with commercial fuel, timing, segregation of SNF categories, and programmatic issues. These are described in the following:

Fuel Durability, Dimensions, and Composition. The DOE SNF has such varied physical dimensions, compositions and cladding materials, generally with higher cladding failure rate than commercial fuel. For example, the N-Reactor fuel has a large number of elements with failed zircaloy cladding which was caused as part of normal operations, when the elements were pushed through the lined graphite channels and dropped onto a trampoline luring removal from the reactor. Other fuels such as the aluminum-clad fuels have experienced high corrosion rates from storage in basins with poor water chemistry or which are beyond the expected storage life. The degree of radiation embrittlement and corrosion product (crud) need to be determined for handling and contamination potential. Standard sized fuel canisters might provide a benefit in allowing for standardized handling and contamination control while being sized to fit into the storage configuration for interim storage as well as an MPC. Spent fuel dimensions and composition must be characterized for storage and transportation requirements, including radiation shielding, decay heat removal and criticality control. In addition, DOE SNF must be further characterized for repository disposal performance assessment in support of licensing requirements which have not yet been finalized. Compatibility of DOE SNF canister materials with the disposal container materials must be determined to protect against galvanic corrosion in an MPC or disposal package.

Potential for Designation as a Hazardous Waste. The Resource Conservation and Recovery Act (RCRA) applies to management and disposal of mixed radioactive and hazardous waste. Some of the DOE SNF contains potentially hazardous materials such as hydrides, carbides, sodium and cadmium. A RCRA compliance study is currently under way as part of the DOE national SNF program to determine how the DOE SNF categories would fit under a hazardous waste category. This could have a significant impact on interim storage and disposal and on the appropriate regulatory courses of action. There is currently no provision for emplacing RCRA waste in the repository.

Temperature Limits of DOE SNF. Commercial fuels which consist of heavy metal oxides and zircaloy cladding have been thoroughly evaluated and determined to be able to withstand a cladding temperature of $340{ }^{\circ} \mathrm{C}$. DOE SNF compositions range from heavy metal oxides to metal alloys and in cladding from zircaloy to aluminum and other metals. Maximum allowable cladding temperatures for aluminum fuels may be significantly lower than for commercial fuels, possibly as low as $150^{\circ} \mathrm{C}$. If a "hot" thermal loading strategy is adopted for the repository, the expected host rock temperatures will be higher than $150^{\circ} \mathrm{C}$. Depending on the cladding conditions, some of the other materials may also have lower temperature limits. Significant research is still needed to develop the technical criteria and accepted thermal performance of the DOE SNF in dry storage.

Criticality Safety. Some of the DOE SNF contains high-enriched uranium (HEU) or plutonium, and criticality control must be developed for storage, transportation and disposal in 
accordance with 10 CFR 71, 10 CFR 72, and 10 CFR 60. Calculations have shown that HEU present in some of the DOE SNF could achieve a criticality with as little as $0.7 \mathrm{~kg}$ in one package during disposal, assuming that the optimal configuration can be attained. ${ }^{9}$ Thus, if the licensing requirements specify that criticality must be avoided even after closure of the repository, large MPCs containing over $100 \mathrm{~kg}$ of HEU would likely not be allowed. A special DOE SNF program task team is currently evaluating the consequences and performance assessment of a criticality event after closure of the repository. ${ }^{10}$

Special Nuclear Materials (SNM) Protection - Safeguards and Accountability. If the disposal of DOE SNM occurs in conjunction with the DOE-OCRWM programs, as is planned, it may be subject to International Atomic Energy Authority (IAEA) safeguards. For example, SNM in commercial fuels is well quantified, clearly marked with alphanumeric identifiers, and nlans for tracking throughout the DOE-OCRWM program are being developed. Similar methodology must be developed for DOE SNM, including those materials which are classified for security. The degree of safeguards depends on the amount of SNM present in the fuel and would be expected to be very stringent for HEU or large amounts of plutonium. Commercial fuel and vitrified HLW are assumed to have low tnc igh fissile content and high radiation fields to consider that diversion for production of nuclear weapons is not likely. The safeguards, once the fuel has been placed in a repository, could range from extensive in-place monitoring of fuel containers to simple monitoring of the storage facility for intrusion. If some of the DOE SNF is placed in large MPCs, significantly large quantities of HEU would be located in one canister and conceivably could be accessible through direct contact mining hundreds of years after disposal, when most of the shorter-lived fission products have decayed.

Repository Waste Package Design Requirements (10 CFR 60.135). Geologic disposal design requirements specified by 10 CFR 60.135 applicable for all waste packages and their components include provisions such as avoiding explosive, pyrophoric and chemically reactive materials, and free liquids; designs with a unique identification which maintain waste containment during transportation, emplacement, and retrieval; waste form criteria that include solidification in a sealed container and consolidation of particulates in an encapsulation matrix; and conversion of combustibles to a non-combustible form. Extensive characterization and/or assessment is required to ascertain whether the expected condition of most DOE fuels at the end of the dry storage period could satisfy these requirements unless significant conditioning were performed prior to placement into dry storage.

Fuel Acceptance Specifications. Current specifications for fuel acceptance at the repository are given generally in 10 CFR 961 and in the Waste Acceptance System Requirements Document (WASRD). ${ }^{11} 10$ CFR 961.5 requires Federal agencies or departments requiring disposal services to sign a suitable agreement reflecting the terms and conditions of $10 \mathrm{CFR}$ 961.11. The commercial fuel acceptance specifications in the WASRD include information on chemical and radionuclide composition, burn-up, heat loading, and criticality control. Adequate quality assurance must be provided in the supporting fuel intormation to meet DOE-OCRWM and NRC requirements. Some performance assessments have been completed or are under way to evaluate the impacts of some of the DOE SNF disposal scenarios. The Team members agreed that while these specifications and the commercial fuel comparisons 
can provide indicators for DOE SNF acceptance, this may not be resolved until actual licensing of the repositury takes placo.

Degree of Similarity of DOE Fuels with Commercial Fuel Storage/Disposal. DOE fuels with a higher degree of similarity to commercial fuel may be more likely to meet the storage, transportation, and disposal requirements assumed for commercial fuel in an MPC. Some DOE-owned fuels, such as the intact commercial fuels, have similar dimensions, enrichment, cladding, burn-up, and other characteristics to commercial fuels which would be placed in MPCs and would not be expected to require additional acceptance requirements. Other DOEowned fuels, such as high-enriched aluminum test reactor fuels have significantly different dimensions and characteristics from commercial fuels and could require additional characterization and waste qualification effort for repository disposal. N-Reactor fuels use low enrichment and zircaloy cladding which are similar characteristics to commercial fuel, but have different dimensions, use a uranium metal alloy rather than uranium oxide, and exhibit a higher percentage of damaged cladding compared to commercial fuel. Standardized canister designs for each DOE fuel type which are compatible with interim storage vaults and commercial MPC designs would be beneficial from systems safety and human factor considerations.

Timing. The timing for removal and interim storage of $i-j$ SNF will be determined by facility vulnerabilities, ${ }^{2}$ state agreements, and licensing or certification of shipping casks and interim storage. The schedule for moving DOE SNF out of some of the old facilities with identified ES\&H vulnerabilities to alternative storage is approximately 8-10 years. ${ }^{6}$ The MPC schedule for commercial fuels includes design specifications for the bid package completed by May, 1994, and fabrication of the first models would be completed by 1998 . If the MPC concept is desired for DOE SNF dry storage, the schedule which is determined by facility vulnerability may require detailed MPC design information before it is available. Significant additional characterization and design effort, resulting in a signed acceptance agreement, similar to 10 CFR 951 for commercial fuels, would likely be required for DOE SNF before sealing the fuel in an MPC with sufficient confidence for repository acceptance as compared to the commercial fuel and HLW glass cases.

Segregation of DOE SNF Categories. Because of the different types of DOE SNF and their characteristics, such as low or high enrichment of fissile materials, one criterion proposed by the team is to keep DOE SNF categories or dissimilar fuel types segregated during interim storage and do not combine with other categories. This would allow conditioning of some categories if deemed necessary with minimum disruption of interim storage of the other categories.

Other Programmatic Issues Impacting Repository Disposal. Programmatic issues which need to be addressed and resolved for DOE SNF disposal in a repository include development of metric tons heavy metal equivalence, declassification of information, repository schedule impacts and consequences, transportation cask and system design and licensing, waste acceptance planning, including completion of a Memorandum of Agreement between DOEEM and -OCRWM, projections of future production, and quality assurance. 


\section{Evaluation of MPC Use for DOE SNF}

The following reviews the bases and drivers which impact DOE SNF interim management and presents the advantages and disadvantages of MPC use. A detailed evaluation of the above criteria as applied to each fuel type is given in Appendix C.

Bases. In order to have common bases for the evaluation, the Team agreed that the MPC consists of a tri-purpose canister used for storage, transportation, and cisposal, which is sealed by welding after loading with fuel and then remains closed throughout interim storage, transportation and emplacement in a repository. The MPC would be considered as part of the waste form during disposal and would be placed in a long-lived overpack at the repository. It would thus not be required to take credit for the complete containment requirement during 300-1000 years given in 10 CFR 60.113. The fuel inside the MPC would have to be sufficiently characterized to meet DOE-OCRWM waste acceptance requirements and NRC licensing. While DOE SNF waste acceptance requirements have not yet been finalized, requirements for any waste in the repository exist in 10 CFR 60, and commercial SNF requirements exist in 10 CFR 961 and the WASRD document." Such requirements include the fuel, cladding and basket material characterization for chemical and radionuclide composition, operating history including burnup, thermal output, and criticality control. The waste form qualification information may be required only to the extent that it will be possible to obtain the characteristics which will bound that particular fuel type. In addition, the MPC and SNF would have to meet transportation requirements, such as limits to hydrogen generation. The DOE SNF National Program has not yet reached a decision concerning the proposed extent of dry versus wet interim storage. Since MPCs are planned for dry commercial SNF storage, in the following evaluations of this White Paper, it was assumed that any interim storage of DOE SNF would use dry storage for comparison.

Drivers. The major drivers which will impact the use and timing of MPCs for DOE SNF include (1) the ES\&H vulnerabilities as identified in the Spent Fuel Working Group, ${ }^{2}$ and resulting action plans, ${ }^{6}(2)$ programmatic dry storage plans with minimum characterization to meet NRC disposal criteria as described in the DOE Spent Fuel Strategic Plan, (3) the DOE program for development of MPCs for commercial fuels, (4) lead time required to secure NRC licensing for storage and transportation casks, MRS, and (5) lead time to provide sufficient DOE SNF testing for characterization and repository performance to secure NRC repository licensing. These drivers have potentially conflicting goals, such as the degree of characterization needed for dry storage compared to repository disposal, and the timing for fuel removal from storage basins considered to have ES\&H vulnerabilities compared to the timing required for sufficient characterization for MPC use.

Advantages of MPCs for DOE SNF. The Team generally agreed that the advantages cited for MPC use for commercial fuel also applied to DOE SNF. These include common handling of standard packages, reduced radiation exposure to the public, containment of contamination, improved human factors and operation efficiency. A common design for all fuel and waste should reduce the overall handling, transportation and repository emplacement costs in a simpler, more integrated operation, thus requiring fewer modifications for DOE-OCRWM to accept DOE SNF. Based on the decision to continue development of an MPC for commercial SNF, any concepts for DOE fuel disposal would have to be compatible with the MPC designs 
at a minimum in handling, transportation and disposal operations. There may be an advantage if the designs for interim storage were within the design envelope for an MPC even if further characterization and stabilization were required prior to disposal.

Disadvantages of MPCs for DOE SNF. Most of the Team members' evaluation focused on the question of feasibility and uncertainty which would drive the development needs and costs and might offset the advantages. The greatest uncertainty focused on repository waste acceptance criteria and if the different DOE fuels would meet the criteria compared to commercial SNF. Waste characterization sufficient to meet similar criteria as for commercial fuel might have to be carried out earlier than previously planned in the DOE SNF National Program and interfere with the desired timing to remove fuel stored in vulnerable basins. If fuel requires further characterization, testing or stabilization to resolve waste acceptance concerns, this would also impact the National Plan timing. The design criteria for the MPC are expected in $5 / 94$. The schedule for detailed design needs to be evaluated to determine if sufficient time is available to be incorporated in DOE SNF interim storage facilities. Much of the DOE fuel should be in interim storage by 2002, which may not leave sufficient time to determine acceptability for repository disposal. Availabie fuel records and QA levels need to be evaluated to determine if sufficient fuel characterization information is available to meet waste acceptance specifications.

\section{Conclusions}

DOE-OCRWM is now proceeding with the next phase of developing the MPC for interim storage, transportation, and disposal of commercial fuel. If the MPC concept is successful for commercial fuel, DOE-owned SNF will eventually have to be interfaced within the MPC design envelope for transportation and disposal to meet the logistics requirements. This White Paper has presented many of the issues, criteria, and other considerations, including facility vulnerabilities, DOE SNF characterization, timing, and waste form qualifications and acceptance, which will have to be considered in determining the timing for adopting the MPC design envelope. The Barrier/Canister Team determined that the degree of characterization of DOE SNF may not be sufficient to meet repository waste acceptance requirements and thus that most of DOE SNF is currently not ready to be sealed into an MPC for final disposal. However, the advantages of standardized package handling, reduced radiation exposure, reduced potential of spread of contamination, improved human factors and reduced operation costs would benefit the DOE SNF program planning for interim storage and transportation and should be included as much as possible. While designs of MPCs for DOE SNF are likely premature at this time, the possibility of designing and using fuel canisters which will be consistent with the interim storage options and MPC design envelope should be pursued. The DOE MPC and DOE SNF programs need to be coordinated through internal agreements to allow for optimum interchange of design information in support of developing DOE interim storage and of eventual interfacing with the MPC design envelope. 


\section{$\underline{\text { Recommendations }}$}

Specific recommendations can be made involving program coordination, systems engineering, fuel characterization, quality assurance, testing, and design of interim storage for DOE SNF:

- The MPC design and development activities under DOE-OCRWM and the DOE SNF interim storage activities under DOE-EM should include a mechanism for interprogram coordination in order that DOE SNF interim storage can be designed with sufficient flexibility for future MPC use, should the MPC become the accepted method for commercial fuel dispositioning.

- As part of the DOE SNF National Program systems engineering study, the use of standard canisters for DOE SNF should be evaluated, including tradeoffs on canister size, existing facility capabilities, and adaptability to proposed interim storage configuration and MPC design dimensions.

- The characteristics of MPCs, including optimum packaging compatible with internal MPC dimensions, reduced radiation exposure, containment of contamination, and improved human factors should be incorporated as much as possible into the designs for interim storage packages of DOE SNF.

- The fuel characterization effort should include compiling records to assess those fuels with well-qualified data, fuels with possible RCRA hazardous materials, and fuels with possible waste-form problems as described in 10 CFR 60.135 , with a goal of determining waste qualification needs for DOE SNF.

- DOE SNF needs to be evaluated for materials characterization needs, and test programs should be developed to evaluate the material performance in interim storage, transportation and disposal.

- The existing quality assurance programs should be upgraded to meet DOE-OCRWM and applicable NRC standards in completing the fuel characterization and eventually meeting waste qualification standards.

- Impacts of criticality and SNM requirements for HEU and other applicable fuels should be continued to be evaluated in coordination with DOE-OCRWM and its M\&O contractors. 


\section{References}

1. U. S. DOE, OCRWM, Conceptual Design for a Waste-Management System that Uses Multipurpose Canisters, DOE/RW-0432 (January 1994).

2. U. S. DOE, Spent Fuel Working Group Report on Inventory and Storage of the Department's Spent Nuclear Fuel and Other Reactor Irradiated Nuclear Materials and their Environmental, Safety and Health Vulnerabilities, Vol. 1 (November 1993).

3. CRWM M\&O Contractor, MPC Implementation Program Conceptual Design Phase Volume I - MPC Conceptual Design Summary Report, Revision 0, A20000000-008115705-00001, TRW Environmental Safety Systems Inc., 2650 Park Tower Drive, Suite 800, Vienna, VA 22180 (September 30, 1993).

4. D. A. Lopez and D. G. Abbott, Feasibility Study for a DOE Research and Production Fuel Multipurpose Canister, EGG-WM-11011 (February 1994).

5. A. P. Hoskins, Personal Communication, "Projected Spent Nuclear Fuel Inventory for EIS Preparation," (April 12, 1994).

6. U. S. DOE, Plan of Action to Resolve Spent Nuclear Fuel Vulnerabilities, Phase I, Vols. I and II (February 1994).

7. M. Louthan, R. Einziger, and M. McKinnon, Technical Issues for Possible Dry Storage of DOE Owned Spent Nuclear Fuels (to be published, 1994)

8. J. Jicha, "The Department of Energy Spent Fuel Program," INMM Spent Fuel Workshop, Washington, D.C. (January 25-28, 1994)

9. H. C. Paxton and N. L. Pruvosp, Critical Dimensions of Systems Containing U-235. Pu-239, and U-233, LA-10860-MS (1968).

10. R. P. Rechard, Editor, Performance Assessment of the Disposal of Spent Nuclear Fuel and High-Level Waste Stored at Idaho National Engineering Laboratory, Appendix on Criticality Modeling (to be published, December 1994).

11. U. S. DOE, OCRWM, Waste Acceptance System Requirements Document (WASRD) Revision 1, DOE/RW-0351P (March 1994). 
APPENDIX A. LIST OF ATTENDEES OF 2/23/94 TEAM MEETING AND WASTE FORM BARRIER/CANISTER TEAM MEMBERS

Attendees of 2/23/94 Meeting

\begin{tabular}{|c|c|c|c|}
\hline NAME & ORGANIZATION & PHONE & FAX \\
\hline Dave Abbott* & EG\&G Idaho & $208-526-0037$ & $208-526-8878$ \\
\hline Gina M. Ban & EG\&G Idaho & $208-525-0619$ & $208-526-7143$ \\
\hline R. L. Bannister & $B \& W$ & $208-526-9929$ & \\
\hline Tom Bechtold & WINCO & $208-526-7738$ & 208-526-4902 \\
\hline Jim Carter & WINCO & $208-526-4406$ & \\
\hline Jerry Christian & WINCO & $208-526-0658$ & $208-526-4902$ \\
\hline James C. Cunnane* & ANL-E & $708-252-4541$ & $708-252-5912$ \\
\hline Ron D. Denney & WINCO & $208-526-3102$ & $208-526-3505$ \\
\hline Denny Fillmore & WINCO & $208-526-3640$ & 208-526-3505 \\
\hline Larry E. Fischer* & LLNL/FESSP & $510-423-0159$ & $510-424-6889$ \\
\hline Roy M. Gale & WINCO & $208-525-0021$ & 208-525-0029 \\
\hline Alan P. Hoskins & WINCO & $208-526-4620$ & $208-526-3505$ \\
\hline Natraj Iyer* & WSRC/SRTC & $803-725-2695$ & $803-725-7369$ \\
\hline Wally Keltner & WINCO & $208-526-3537$ & $208-526-4741$ \\
\hline Ron Klingler & WINCO & $208-526-0183$ & 208-526-7392 \\
\hline Dieter A. Knecht* & WINCO & $208-526-3627$ & 208-526-3499 \\
\hline N. Prasanna Kumar* & DOE-HQ/RW-421 & $202-586-8980$ & \\
\hline Henry H. Loo & WINCO & $208-526-3332$ & 208-526-7392 \\
\hline Ron E. Mizia* & WINCO & $208-526-3352$ & $208-526-6517$ \\
\hline Marcia J. Monthey* & WHC & $509-376-0693$ & \\
\hline David Ostby & WINCO & $208-525-0015$ & 208-525-0029 \\
\hline Dave Rosine* & DOE-OR & $615-574-8640$ & $615-574-8649$ \\
\hline Kristine Svinicki & DOE-ID & $208-526-6680$ & $208-526-5678$ \\
\hline Tom Thomas & WINCO & $208-526-3086$ & $208-526-4902$ \\
\hline Gene Woodall* & DOE-ID & $208-526-8504$ & $208-526-5678$ \\
\hline Richard Wright & B\&W Idaho & $208-526-5062$ & \\
\hline
\end{tabular}

* Member of Waste Form Barrier/Canister Team 
Membership of Waste Form Barriır/Canister Team

David G. Abbott

EG\&G Idaho, MS 2420

208-526-0037,FAX 526-8878

Alan Berusch

DOE-RW-22

202-586-9362, FAX -1207

Brett W. Carlsen

WINCO/AT-Systems Integration

208-526-3347, FAX -7392

Willis L. (Bill) Clarke

LLNL

510-423-4571, FAX -1997

Harold J. Cleary

Roy F. Weston, Inc.

202-646-6728, FAX-863-2220

James C. Cunnane

Argonne National Laboratory

708-252-4541, FAX -5912

Thomas W. Doering

B \& W Fuels

702-794-7680, FAX -1844

Larry Fischer

LLNL

510-423-0159, FAX 424-6889

Bob Fish

B \& W Fuels

702-794-1805, FAX -1844

Brian Flaspohler

DOE-EM-323

301-903-3282, FAX -6282

Natraj Iyer

SRTC

803-725-2695, FAX -7369
Dieter A. Knecht

WINCO-AT

208-526-3627, FAX -3499

Prasanna N. Kumar

DOE, RW-421

202-586-8980, FAX -9608

Mac Louthan

Savannah River Technology Center

803-725-5772, FAX -7369

Paul McConnell

Sandia National Laboratories

505-845-8361, FAX-844-0244

Ronald E. Mizia, Advisory Engineer WINCO-AT/Spent Fuel-Metal Recycle 208-526-3352, FAX -6517

Marcia J. Monthey

Westinghouse Hanford Co. 509-376-0693, FAX -7750

David Rosine

DOE-ORO

615-574-8640, FAX -8649

P. Stephen Schaus

Westinghouse Hanford Co.

509-372-1149, FAX -1147

Kenneth R. Schneider

West Valley Nuclear Services

716-942-4671, FAX - $4246 / 4376$

MacKaye W. Smith

DOE-YMP

702-794-1933, FAX -7907

Paul E. (Gene) Woodall

DOE-ID

208-526-8504, FAX -5678 


\section{APPENDIX B. DETAILED DESCRIPTION OF DOE SNF CHARACTERISTICS AND QUANTITIES}

The DOE SNF is grouped into 8 categories. The categories are labeled "Jicha Cat. 1, 2, 3, 4, $5,6 \mathrm{a}, 6 \mathrm{~b}$, and $6 \mathrm{c}$ " and are an attempt to group similar fuel types. 
SNF \& ERMWM EIS Spent Nuclear Fuel Inventorice Including Non-DOE locations - 8/1/ 1095 JICHA
Cat.

Fuel

Name

Naval Fuol

1 INEL CPP-603

INEL CPP-BBB

Naval
Naval

50000

300000

80

350000

1 INEL Subtotal

1 NRF ECF

NRF Prototype

1 NRF Subtotal

1 Other Navy

1 Other Navy Subtotal
Total

(kg)
Naval
39000

189000
No. Items
Units Uranlum

(m3)

(kg)
Uranium
Enrich.

()
13Jul-94

050

5000

6850

2500

570

3070
MTHM

Fissile

(kg) (M-ton)

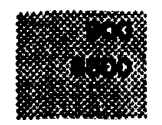

6700

2500

570

3070
0.947

5.8

6.847

2.5

0.6

3.1

$\begin{array}{rrr}95 & 600 \\ & & \\ 37 & 240 \\ 11 & 48 & \\ 48 & 288 & 0\end{array}$$$
48
$$

1 TOTAL

$339000 \quad 143 \quad 1088$

9920

9770

9.947

SRS \& Al Fuel

2 Brookhave BMRR

BMRR

0.03 36 assem

1.88

89.9

2.7

0.003

2 Brookhave HFBR

HFBR

900

937 unit

250

93

2 Brookhaven Subtotal

900

$3.23 \quad 973$

251.88

205.7

0.255

2 INEL TRA-660

ARMF/CFRMF

$\begin{array}{lll}0.076 \quad 67 & \text { unlt }\end{array}$

14.1

93

12.5

0.014

INEL TRA-670

INEL TRA-660

INEL TRA-670

INEL ATR corO

INEL CPP-66B

INEL CPP-603

INEL CPP-603

INEL CPP-603

INEL CPP-603

INEL CPP-666

INEL CPP-666

INEL CPP.686

INEL CPP-686

ATA recycle

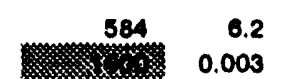

591 elem

472

409

0.42

0.472

ATR spent

ATR

ARMF

940

1.3

02 assem

102.50 .98

40 olem

$\begin{array}{llll}3.6 & 0.014 & 15 & \text { plate }\end{array}$

$937.5 \quad 1 \quad 109$ assom

HFBA

87.3

0.075

10 assm

MURR

ORR

ATR

HFBR

MURR

$U$ of Wash

$\begin{array}{ll}158 & 0.24\end{array}$

25 assm

$\begin{array}{llll}85 & 0.07 & 17 & \text { assm }\end{array}$

$9000 \quad 9 \quad 1027$ assm

$\begin{array}{llll}1013 & 0.885 & 221 & \text { assom }\end{array}$

$\begin{array}{llll}198 & 0.3 & 31 & \text { assem }\end{array}$

$\begin{array}{ll}70 & 0.07\end{array}$

20 bund

217 depleted

82.6

78

0.217

$\begin{array}{llll}46.1 & 83 & 40.8 & 0.046\end{array}$

$\begin{array}{llll}0.2 & 90 & 0.18 & 0.0002\end{array}$

$\begin{array}{llll}90.5 & 82 & 74.82 & 0.098\end{array}$

5

79.0

87.5

4

0.005

17

3.3

80

14.8

0.018

821

82

70.9

$\begin{array}{llll}21 & 87.5 & 18.5 & 0.022\end{array}$

673

0.0033

0.83

0.0584

$\begin{array}{llll}4.1 & 03.6 & 3.6 & 0.0041\end{array}$

2 INEL Subtotal

2 LANL CMR

2 LANL POOI

OMEGA.W

$14798.9 \quad 20.173$

2281

1863.7

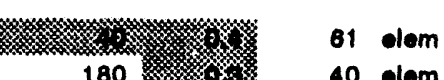

12.25

$\begin{array}{ll}1378.92 & 1.881\end{array}$

OMEGA-W

180

40 elem

$\begin{array}{lll}220 & 0.7 & 101\end{array}$

21.25

93

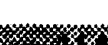

0.012

8

93

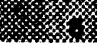

0.000

2 LANL Subtotal

SRS U-233
Hanford U-233
BSR
ORR
HIFR
TSR

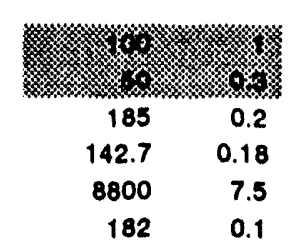

144 can

41 can

$\begin{array}{ll}41 & \text { olem } \\ 32 & \text { unit }\end{array}$

60 assm

1 assom

$\begin{array}{lll}9459.7 & 9.28 & 310\end{array}$

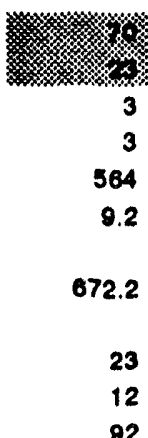

19.4

0.021
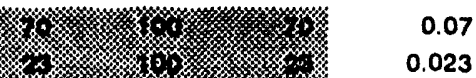

$\begin{array}{llll}3 & 93 & 2.4 & 0.003\end{array}$

$\begin{array}{llll}3 & 19.8 & 0.6 & 0.003\end{array}$

$\begin{array}{llll}564 & 93 & 525 & 0.57\end{array}$

$\begin{array}{lllll}9.2 & 93 & 8.6 & 0.0092\end{array}$

2 ORNL Subtotal

10 elom

SANDIA SNM stor

CX

SPR-II

SPR-II

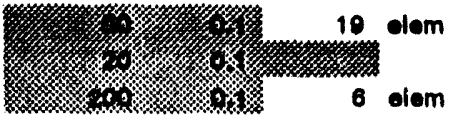

972.2

629.60 .6782

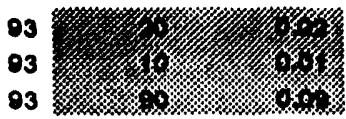


SNF A ERWM EIS Spent Nuclear Fuel Inventories Including Non-DOE locations - 6/1/ 1995 JICHA Loontion Faollty Cat.

$\begin{array}{lll}2 & \text { SANDIA } & \text { SPR } \\ 2 & \text { SANDIA } & \text { SPR }\end{array}$

Fud
Namo
SPR-HIIII
SPR-III

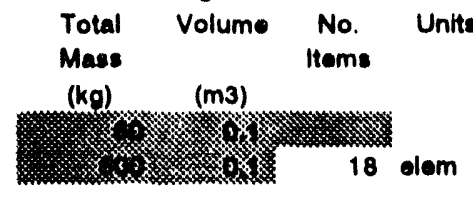

2 SANDIA Subtotal

$\begin{array}{lll}2 & \text { SRS } & \text { F-CANYO } \\ 2 & \text { SRS } & \text { H-CANYO } \\ 2 & \text { SAS } & \text { K-BASIN } \\ 2 & \text { SRS } & \text { KLP-BASI } \\ 2 & \text { SAS } & \text { L-BASIN } \\ 2 & \text { SAS } & \text { L-BASIN } \\ 2 & \text { SAS } & \text { P-BASIN } \\ 2 & \text { SRS } & \text { RBOF } \\ 2 & \text { SRS } & \text { RBOF } \\ 2 & \text { SRS } & \text { RBOF } \\ 2 & \text { SRS } & \text { RBOF } \\ 2 & \text { SRS } & \text { RBOF } \\ 2 & \text { SRS } & \text { RBOF } \\ 2 & \text { SAS } & \text { RBOF } \\ 2 & \text { SAS } & \text { RBOF } \\ 2 & \text { SAS } & \text { RBOF } \\ 2 & \text { SRS } & \text { RBOF } \\ 2 & \text { SRS } & \text { RBOF } \\ 2 & \text { SRS } & \text { RBOF } \\ 2 & \text { SRS } & \text { RBOF } \\ 2 & \text { SRS } & \text { RBOF } \\ 2 & \text { SRS } & \text { RBOF } \\ 2 & \text { SRS } & \text { RBOF } \\ 2 & \text { SRS } & \text { RBOF } \\ 2 & \text { SRS SUbtOLI } \\ & & \end{array}$

\author{
Targot
}

Driver

Driver

non U Target

Driver

$$
\text { Target }
$$

Driver

ANL Janus

ASTR

JMTR

MIT

MURR

Nereide

ORR-LEU

ORA

RHF

AINC

Sterling Forest

Tawwan RA

$U$ of Michigan

$U$ of Virginia

EBR-II Target

target samples

Foreign from reliet

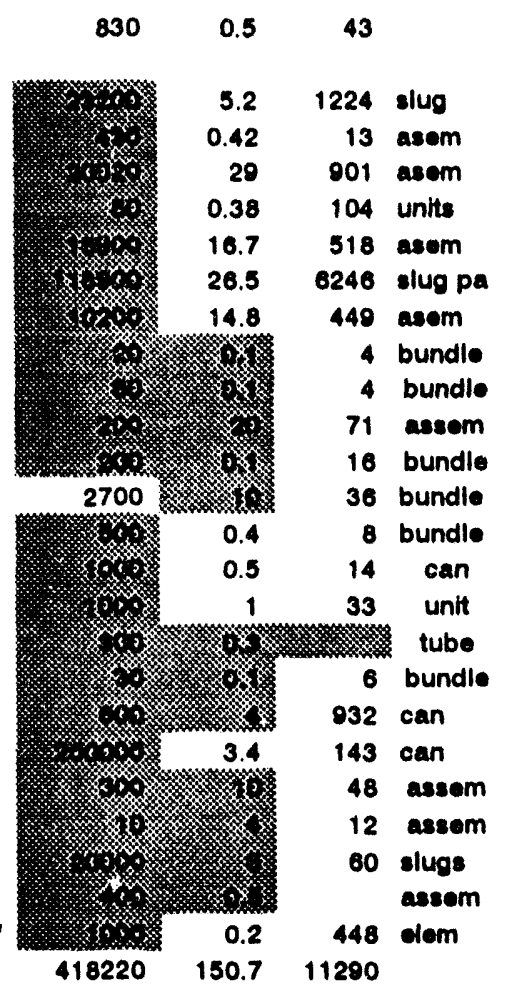

2 Mbcellaneous Faolltite

2 Pleasanton

2 Galthersburo

GENTR
NIS

2 Miscellaneous Facllities 3ubtotal

2 Univeraity

2 MIT

2 Cornall

2 U of Florida

2 Georgia

2 lowa St.

2 of Mass Lowell

2 Manhattan

2 U of Miohigan

2 MURR Col.

2 MURR Rol.

2 N. Carolina

2 Ohio St.

2 Purdus

2 Rhode le.

$2 U$ of Virginia

2 Worcester

2 Univerelty Subtotal

2 TOTAL

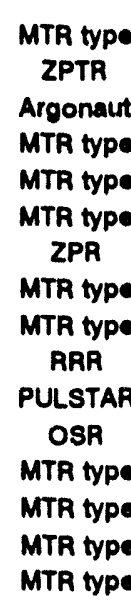

MTR type
MTR type

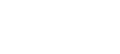
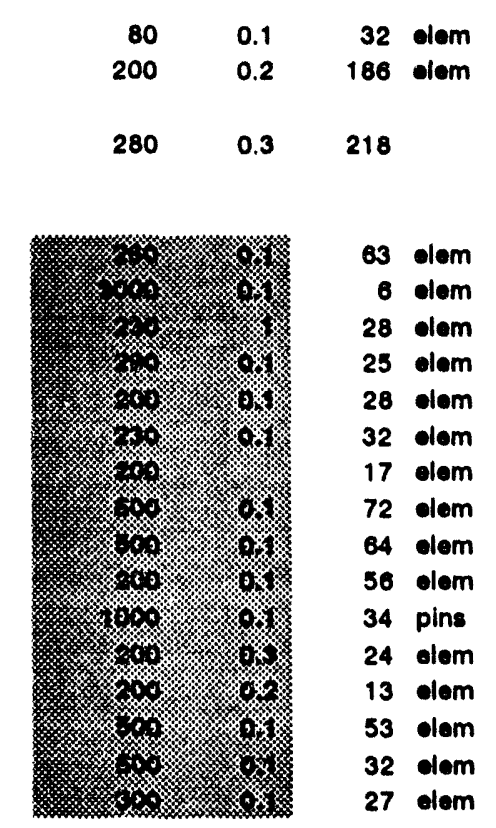

63 dem

6 elem

28 elem

23 elam

28 elem

32 elem

17 elem

72 elem

64 elem

56 elem

34 pins

24 olom

13 elem

53 elem

32 tom

27 elem

74 $\begin{array}{lll}8310 & 2.7 & 574\end{array}$

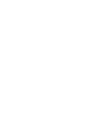

$453024.6 \quad 187.58 \quad 15790$
22612

67.8

3237

0.04

2593

115383

1391.2

2.70

3.22

16.7

15.93

48.6

35.42

95

116

25.5

3.7

123

20469

33.85

1.9

16983

369.3

83687

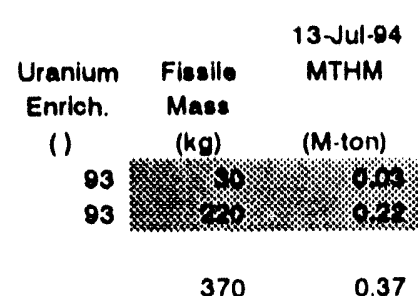

$\begin{array}{rrr}0.18 & 42 & 22.634 \\ 61 & 41.4 & 0.068 \\ 66 & 2113.5 & 3.256 \\ 0 & 4.2 & 0.059 \\ 60 & 1546 & 2.613 \\ 0.18 & 211 & 115.498 \\ 66 & 921.3 & 1.408 \\ 93 & 2.59 & 0.003 \\ 93 & 3 & 0.003 \\ 80 & 14.8 & 0.0167 \\ 81 & 12.92 & 0.016 \\ 87 & 42.2 & 0.0486 \\ 19.8 & 7 & 0.035 \\ 15.7 & 15 & 0.0157 \\ 27 & 31.9 & 0.115 \\ 81 & 20.78 & 0.0255 \\ 89 & 3.3 & 0.0037 \\ 91 & 112 & 0.123 \\ 0.63 & 128 & 21 \\ 15 & 4.98 & 0.0339 \\ 89 & 1.7 & 0.0019 \\ 0.25 & 194 & 17 \\ 0.2 & 0.67 & 0.37 \\ 60 & 36 & 0.06 \\ & 5510.22 & 184.407\end{array}$

8
40

$\begin{array}{rrr}93 & 7.2 & 0.008 \\ 93 & 37 & 0.04 \\ & & \\ & 44.2 & 0.048\end{array}$

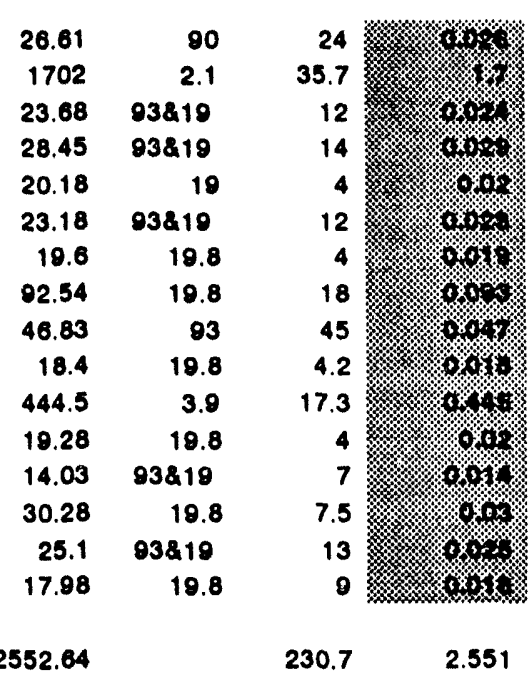

189481.0

$8388.74 \quad 180.2112$ 
SNF \& ERMM EIS Spent Nuclear Fuel Inventories Including Non-DOE locationa - 6/1/ 1995

\begin{tabular}{|c|c|c|c|c|c|c|c|c|c|c|c|}
\hline \multicolumn{2}{|c|}{$\begin{array}{l}\text { JICHA Loontion } \\
\text { Cat. }\end{array}$} & Facility & $\begin{array}{l}\text { Fuol } \\
\text { Name }\end{array}$ & $\begin{array}{l}\text { Total } \\
\text { Mass } \\
(\mathbf{k g})\end{array}$ & $\begin{array}{l}\text { Volume } \\
\text { (m3) }\end{array}$ & $\begin{array}{l}\text { No. } \\
\text { ltems }\end{array}$ & Units & $\begin{array}{l}\text { Uranium } \\
M: \text { so } \\
\text { (kg) }\end{array}$ & $\begin{array}{l}\text { Uranium } \\
\text { Enrich. } \\
\text { (1) }\end{array}$ & $\begin{array}{l}\text { Fiaslle } \\
\text { Mases } \\
(\mathbf{k g})\end{array}$ & $\begin{array}{l}\text { MTHM } \\
\text { (M-ton) }\end{array}$ \\
\hline \multicolumn{12}{|c|}{ Hanford Fuel } \\
\hline 3 & Mantord & KE-BASIN & N Reactor & 1234801 & 112 & 3687 & canst & 1143800 & 0.95 & 10142 & 1145.96 \\
\hline 3 & Hantord & KE-BASIN & SPR & 408 & 0.04 & 4 & canst & 400 & 0.95 & 4 & 0.4 \\
\hline 3 & Manford & KW-BASI & N Reactor & 1027818 & 93 & 3815 & canst & 951900 & 1.08 & 14030 & 053.8 \\
\hline 3 & Hanford & $K W \cdot B A S I$ & SPR & 102 & 0.01 & 2 & oanat & 100 & 1.15 & 1.15 & 0.1 \\
\hline 3 & Hanford & PUREX & N Reactor & 291 & 0 & 20 & olom & 207 & 0.08 & 2.528 & 0.3 \\
\hline 3 & Hantord & PUREX & SPR & 2027 & 0.2 & 770 & alom & 2870 & 0.064 & 1.837 & 2.87 \\
\hline 3 & TOTAL & & & 2260437 & 205.28 & 8287 & & 2009337 & & 30100.5 & 2103.43 \\
\hline \multicolumn{12}{|c|}{ Graphlte Fuel } \\
\hline 4 & INEL & CPP-IFSF & Peachbottom core 1 & 730 & 0.82 & 18 & elem & 4.6 & 75.7 & 4.4 & 0.046 \\
\hline 4 & INEL & CPP.IFSF & Panohbottom core 2 & 33000 & 15.7 & 780 & elom & 126 & 53.3 & 110 & 1.3 \\
\hline 4 & INEL & CPP.740 & Peachbottom core 1 & 32270 & 36.2 & 796 & elom & 202 & 75.7 & 194 & 1.054 \\
\hline 4 & INEL & CPP-IFSF & FSVR & 95000 & 80 & 744 & asem & 308 & 54 & 180 & 8.6 \\
\hline 4 & \multicolumn{2}{|c|}{ INEL Subtotal } & & 101000 & 132.72 & 2347 & & 040.0 & & 306.4 & 11.6 \\
\hline 4 & \multicolumn{2}{|c|}{ Pub. Sor. o FSVA } & FSVR & 100000 & 160 & 1446 & assem & 616 & 54 & 333 & 16 \\
\hline 4 & \multicolumn{2}{|c|}{ Pub. Sor. Subtotal } & & 150000 & 100 & 1448 & & 016 & & 333 & 16 \\
\hline 4 & ORNL & Bld 7829 & Peachbottom & 552 & 0.5 & & & 3 & 76 & 2 & 0.003 \\
\hline 4 & \multicolumn{2}{|c|}{ ORNL Subtotal } & & 352 & 0.5 & 0 & 0 & 3 & 76 & 2 & 0.003 \\
\hline 4 & TOTAL & & & 351552 & 203.22 & 3703 & & 1250.6 & & 841.4 & 27.603 \\
\hline \multicolumn{12}{|c|}{ Commerclal Fual } \\
\hline 5 & ANL-E & Hot cell & Commercial & 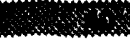 & 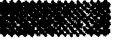 & 1 & canat & 19.5 & 4.7 & 0.0 & 0.010 \\
\hline 5 & \multicolumn{2}{|c|}{ ANL-E Subtotal } & & 40 & 0 & 1 & & 19.5 & & 0.0 & 0.019 \\
\hline 5 & Hanford & Bld 324,5 & LWR & 100 & 4.1 & 10 & cask & 93 & 2 & 4 & 0.09 \\
\hline 5 & Hanford & Bld 324,5 & Calvert Cliffe (PWR) & 1000 & 0.37 & 2 & assem & 663 & 0.64 & 18 & 0.67 \\
\hline 5 & Hanford & Bld-324,5 & Cooper (BWR) & 300 & 0.17 & 2 & aseem & 365 & 0.00 & $\bullet$ & 0.37 \\
\hline 5 & Hanford & Bld 324,5 & HB Robinson (PWR) & 50 & 0.005 & 14 & rod & 30 & 0.72 & 1 & 0.03 \\
\hline 5 & Hanford & Bld-324,5 & Point Boach-1 (PWR) & 1500 & 0.56 & 3 & asem & 1151 & 0.89 & 35 & 1.16 \\
\hline \multicolumn{3}{|c|}{5 Hanford Subtotal } & & 3150 & 5.205 & 31 & & 2302 & & 07 & 2.32 \\
\hline 5 & INEL & CPP-603 & Pulatar Butfalo & 332 & 0.1 & 24 & can & 251.4 & 4.8 & 13.5 & 0.252 \\
\hline 5 & INEL & TRA-603 & OPTRAN & 28 & 0.08 & $\mathbf{s}$ & ounst & 10.7 & 2.5 & 0.63 & 0.0107 \\
\hline 5 & INEL & TRA.603 & CANDU & 19.4 & 0.03 & 2 & canst & 2.6 & 9.8 & 0.26 & 0.0026 \\
\hline 5 & INEL & TRA-603 & Dreaden SA-1 & 40.4 & 0.13 & 31 & rod & 18.6 & 2.1 & 0.54 & 0.0186 \\
\hline 5 & INEL & TAA.603 & GAP CON & 12.5 & 0.08 & 14 & rod & 8.94 & 10 & 0.89 & 0.0089 \\
\hline 5 & INEL & TRA-603 & HALDEN IFA & 3.3 & 0.07 & 5 & rod & 2.3 & 9.6 & 0.23 & 0.0023 \\
\hline 5 & INEL & TAA.003 & HE Robinson & 8.9 & 0.08 & 5 & canst & 6.3 & 0.75 & 0.13 & 0.0063 \\
\hline 5 & INEL & TRA.603 & Halden & 6.5 & 0.07 & 13 & rod & 4.55 & deplcted & 0.46 & 0.0045 \\
\hline 5 & INEL & TRA-603 & LOFT LEAD ROD & 5 & 0.02 & 7 & rod & 3.5 & 9.3 & 0.33 & 0.0035 \\
\hline 5 & INEL & TRA.603 & MAPI & 31.8 & 0.96 & 40 & rod & 22.3 & 5.7 & 1.30 & 0.022 \\
\hline 5 & INEL & TRA-603 & Peachbottom & 13.4 & 0.08 & 5 & canst & 0.4 & 1.4 & 0.22 & 0.0094 \\
\hline 5 & INEL & TRA.603 & RIA & 8.6 & 0.08 & 8 & canat & 0.1 & 5.7 & 0.36 & 0.0081 \\
\hline 5 & INEL & TRA-603 & Saxton & 10.2 & 0.115 & 18 & rod & 7.1 & 8.9 & 0.68 & 0.0080 \\
\hline 5 & INEL & TRA.603 & TC & 3.6 & 0.03 & 0 & rod & 3.1 & 10 & 0.3 & 0.0031 \\
\hline 5 & INEL & TAN-607 & BCD-LFASB & 441 & 0.10 & 1 & asem & 310 & 0.5 & 5.3 & 0.31 \\
\hline 5 & INEL & TAN-607 & Con Yanke & 540 & 0.10 & 1 & asem & 380 & 1.4 & 10.0 & 0.38 \\
\hline 5 & INEL & TAN.607 & Peachbottom & 234 & 0.17 & 1 & asem & 107 & 1.4 & 5.2 & 0.167 \\
\hline 5 & INEL & TAN-607 & Poachbottom & 271 & 0.17 & 1 & asem & 188 & 0.7 & 13 & 0.188 \\
\hline
\end{tabular}


SNF ERMM EIS Spent Nuclear Fud Inventories Inoluding Non-DOE locations - 6/1/ 1995

\begin{tabular}{|c|c|c|}
\hline $\begin{array}{c}\text { JlCHA } \\
\text { Cat. }\end{array}$ & atton & Faollity \\
\hline 6 & INEL & TAN-607 \\
\hline 5 & INEL & TAN-701 \\
\hline $\mathbf{s}$ & INEL & TAN-607 \\
\hline 5 & INEL & TAN-791 \\
\hline 5 & INEL & TAN-607 \\
\hline s & INEL & TAN-607 \\
\hline 5 & INEL & TAN-607 \\
\hline 5 & INEL & TAN-607 \\
\hline 6 & INEL & TAN-701 \\
\hline
\end{tabular}

Fual
Name
Surry
BCD B17
Dreaden
EMAD
HB Robinson
LOFT
LOFT fines
TMI-2
DRCT

\begin{tabular}{|c|c|c|c|}
\hline $\begin{array}{l}\text { Total } \\
\text { Mass } \\
\text { (kg) }\end{array}$ & Volume & $\begin{array}{l}\text { No. } \\
\text { Items }\end{array}$ & Units \\
\hline 20000 & 0.16 & 33 & assm \\
\hline 657 & 0.10 & 1 & asem \\
\hline 235 & 0.13 & 55 & rod \\
\hline 3084.6 & 0.94 & 5 & assm \\
\hline 367 & 0.40 & 125 & rod \\
\hline 3600 & 1.3 & 14 & asem \\
\hline 6.2 & 0.001 & 5 & can \\
\hline 120000 & 120 & 342 & canst \\
\hline 30000 & 4.54 & 24 & can \\
\hline
\end{tabular}

5 INEL subtotal

5 Lynohburg
5 Lynohburg
5 Lynohburg
5 Lynohburg
5 Lynchburg
5 Lynohburg

Arkaneas-1
Con Edkon
Ocone-1
Oconee-1
Oconee-2
TMl-2

$170059.4 \quad 145.4$

800

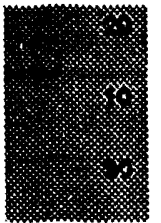

0.03

0.03

0.05

4 canst

Uranium

Mase

(kg)

14000

410

165

2200

257

2200

4.33

82000

21000

Uranium

Enrich.

Fiselle

13-Jul-o4

MTHM

ch. Mass

(M-ton)

0.8

(kg)

291

14

$\begin{array}{ll}8.2 & 0.41\end{array}$

depleted

0.7

0.165

2.2

$\begin{array}{rrr}0.7 & 5 & 0.257 \\ 4.1 & 90.2 & 2.2\end{array}$

$4.1 \quad 90.2$

0.0105

2100

82

21

5 Lynohburg subtotal

60

0.11

15

Con. Edison

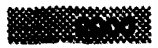

1405 can

rod

BR3

GETR

OANL BLD-4501

ORNL BLD-4501 HB Robinson (PWA)

ORNL BLD-4501 Monticello (BWA)

ORNL BLD-4501 Oconee-1 (PWR)

ORNL BLD-4501 Peachbottom

ORNL BLD-4501 Quad Cty-1 (BWR)

ORNL

ORNL Various Various Commercial

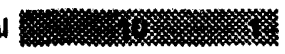

40 Section

123647.2

$3014.67 \quad 123.6554$

$\begin{array}{llll}11.70 & 0.4 & 0.05 & 0.015\end{array}$

7.91

1.3

$$
0.1
$$

0.008

19.5

0.9

0.17

0.021

39.17

0.32

0.044

1215

5 沙

1.215

cap

rod

rod

rod

rod

rod

ORNL uubtotal

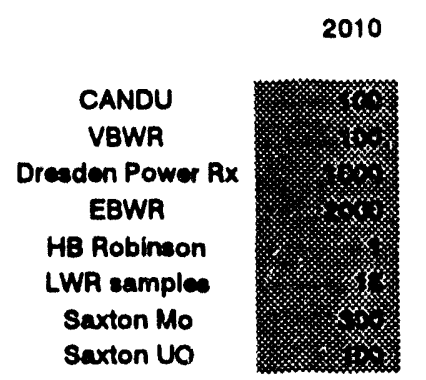

2

445

7
1222

5

0.35

0.007

5 SRS RBOF

5 SAS RBOF

5 SRS RBOF

5 SRS RBOF

b SRS REOF

5 SRS RBOF

5 SAS RBOF

5 SRS RBOF

5 SAs subtotal

5 Westvalley FRS

5 Weatvalley FRS

Big Rock (BWA)

3616

0.18

0.003

1.1

0.86

0.008

0.03

0.48

0.5

6 can

4 bundle

30 units

60 assm

1 cans

5 cans

9 cans

5 cans

50.2

0.46

60.35

1.222

50.2
11.9

10.4

0.23

0.0502

684

9958

5.5

1.24

0.012

0.5

12.6

283

89.2

0.7

37.6

2.5

$0.720 .004 \quad 5 E-05$

$1.5 \quad 0.4$

0.012

0.47

32.3

0.283

0.089

Big Rock (BWR)
Gina (PWR)

5 WestValley Subtotal

5 Total.

$230835.4 \quad 160.65$

164318.3

4490.0

158.80665

Experinental SsT Fuel

a ANLE Hot coll

EBR-II FFTF

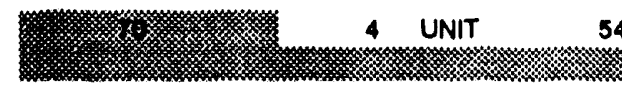

ca ANL-E Subtotal

70

o

4

54

46

46

0.06 
SNF \& ER/WM EIS Spent Nuclear Fuel Inventories including Non-DOE locations - 8/1/ 1905

\begin{tabular}{|c|c|c|c|c|c|c|c|c|c|c|c|}
\hline $\begin{array}{c}\text { JICHA } \\
\text { Cat. }\end{array}$ & Location & Facility & $\begin{array}{l}\text { Fuel } \\
\text { Name }\end{array}$ & $\begin{array}{c}\text { Total } \\
\text { Mass } \\
(\mathrm{kg})\end{array}$ & $\begin{array}{l}\text { Volume } \\
\text { (m3) }\end{array}$ & $\begin{array}{l}\text { No. } \\
\text { Itoms }\end{array}$ & Units & $\begin{array}{c}\text { Uranium } \\
\text { Mass } \\
\text { (kg) }\end{array}$ & $\begin{array}{l}\text { Uranium } \\
\text { Enrich. } \\
\text { () }\end{array}$ & $\begin{array}{l}\text { Fisalle } \\
\text { Mass } \\
(\mathbf{k g})\end{array}$ & $\begin{array}{l}\text { MTHM } \\
\text { (M-ton) }\end{array}$ \\
\hline $6 \mathbf{a}$ & ANL-W & EBR-II & EBR-II & 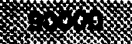 & 滥 & 225 & assm & 15000 & $66 \& 2$ & Kx. & 22.9 \\
\hline $6 a$ & ANL-W & HFEF & EBR-II & 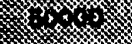 & 1 & 90 & assm & 11000 & $66 \& 2$ & 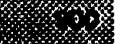 & 11.80 \\
\hline $6 \mathbf{a}$ & ANL-W & NRAD & NRAD & \% & $10 \%$ & 61 & elom & 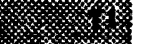 & 64 & 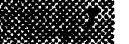 & 0.011 \\
\hline $\begin{array}{l}6 a \\
6 a\end{array}$ & ANL-W & RSWF & EBA-II & 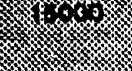 & s. & 1500 & units & (1) & & 䋈 & 11.33 \\
\hline $\begin{array}{l}6 a \\
6 a\end{array}$ & ANL-W $z$ & ZPPR & ZPPR & 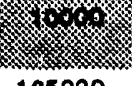 & 栘 & 1710 & can & 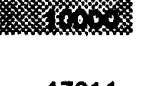 & & 6000 & 9.47 \\
\hline $6 \mathbf{a}$ & ANL-W Subt & ototal & & 165020 & 203.04 & 3588 & & 47011 & & 17607 & 55.601 \\
\hline $6 \mathbf{a}$ & Hanford & AREA 200 & TRIGA AL OSU & 216 & 2.7 & 90 & assm & 17.2 & 10 & 3 & 0.02 \\
\hline $6 a$ & Hanford & Area-200 & EBR (LANL) & 400 & 16.4 & 24 & cask & 200.5 & 0.336 & 151 & 0.2 \\
\hline ba & Hanford & Area-200 & GETCF \& SEFOR & 300 & 3.3 & 22 & cask & 45.2 & 0.100 & 14 & 0.05 \\
\hline $6 a$ & Hanford & BLDG30 & TAIGA Al & 80 & 0.02 & 35 & assem & 12.2 & 20 & 2 & 0.01 \\
\hline ea & Hanford & Bld-308 & TRIGA SST & 160 & 0.04 & 68 & assem & 6.7 & 20 & 1 & 0.01 \\
\hline $6 a$ & Hanford & Bld-327 & EBR-II & 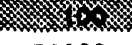 & 媇 & 1 & cask & 17 & 0.35 & 6 & 0.02 \\
\hline $6 a$ & Hanford & FFTF & FFTF & 58000 & 16.5 & 341 & assm & 8400 & 0.7 & 52.58 & 11 \\
\hline $6 a$ & Hanford Suk & Ibtotal & & 59256 & 41.16 & 579 & & 8698.8 & & 229.58 & 11.31 \\
\hline $6 a$ & INEL & CPP-603 & Al & 10 & 0.04 & 12 & can & 7.9 & 92.1 & 7.3 & 0.0079 \\
\hline $6 a$ & INEL & CPP-603 & APPR (AGE-2) & 2.3 & 0.012 & 1 & can & 0.2 & 90.0 & 0.18 & $2 E-05$ \\
\hline $6 a$ & INEL & CPP-603 & BMI & 22.5 & 0.017 & 3 & can & 1.9 & 65.9 & 1.22 & 0.0018 \\
\hline 6a & INEL & CPP-603 & BORAX V & 150 & 0.3 & 36 & assm & 28 & 93.2 & 24 & 0.021 \\
\hline $6 a$ & INEL & CPP-603 & EBA-II & 1300 & 2.85 & 2163 & can & 1190 & 62.3 & 714 & 1.2 \\
\hline $6 a$ & INEL & CPP-603 & EBR-II ANL-6 & 5 & 0.006 & 4 & can & 1.6 & 51.0 & 0.84 & 0.0016 \\
\hline $6 a$ & INEL & CPP.603 & GCRE can & 1.5 & 0.01 & 1 & can & 0.8 & 93 & 0.84 & 0.0009 \\
\hline $\mathbf{6 a}$ & INEL & CPP-603 & GCRE pellots & 1 & 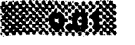 & 1 & can & 0.1 & 93 & 0.1 & 0.0001 \\
\hline $6 \mathbf{a}$ & INEL & CPP.603 & GETR Filters & 50 & 0.10 & 10 & belt & 4.4 & 92.3 & 4.1 & 0.0044 \\
\hline $6 a$ & INEL & CPP-603 & Pathfinder & 960 & 1.36 & 417 & rod & 53.41 & 92.1 & 49.2 & 0.0534 \\
\hline $6 \mathbf{a}$ & INEL & CPP-603 & SM-1A & 786 & 1.2 & 93 & assm & 65.8 & 86.1 & 56.6 & 0.0658 \\
\hline 6a & INEL & CPP-603 & SNAP & 50 & 0.1 & 10 & can & 21 & 93.3 & 10.6 & 0.029 \\
\hline $6 a$ & INEL & CPP-603 & SPEC (Orme) & 7.5 & 0.005 & 1 & can & 2.4 & 5 & 0.123 & 0.002 \\
\hline $6 \mathbf{a}$ & INEL & CPP.603 & SPSS (Spert) & 5.5 & 0.012 & 1 & can & 0.6 & 92.9 & 0.548 & 0.001 \\
\hline $6 \mathbf{a}$ & INEL & CPP.603 & TRIGA Al & 1700 & 0.45 & 578 & rod & 104.4 & 10.7 & 20.6 & 0.1 \\
\hline $6 a$ & INEL & CPP.603 & TRIGA FLIP & 22 & 0.01 & 2 & can & 1.2 & 67.8 & 0.8 & 0.0012 \\
\hline $6 a$ & INEL & CPP.603 & TRIGA SST & 84 & 0.21 & 263 & olem & 49.2 & 18.8 & 0.2 & 0.049 \\
\hline $\mathbf{6 a}$ & INEL & CPP.603 & Tory-\|A & 2000 & 0.84 & 146 & can & 48.7 & 93.2 & 45.3 & 0.0487 \\
\hline $6 \mathbf{a}$ & INEL & CPP-603 & VBWR (Geneva) & 24 & 0.07 & 4 & can & 12.4 & 21.1 & 2.6 & 0.012 \\
\hline $6 a$ & INEL & CPP-668 & EBR-II & 900 & 1.96 & 1492 & can & 820 & 62.3 & 492 & 0.83 \\
\hline $6 \mathbf{a}$ & INEL & CPP.749 & Fermi blanket & 50000 & 18.7 & 14 & can & 34000 & 0.4 & 133 & 34.17 \\
\hline $6 a$ & INEL & CPP.IFSF & Tory-11C & 2500 & 3.5 & 655 & tube & 59.1 & 93.1 & 55 & 0.059 \\
\hline $6 \mathbf{a}$ & INEL & PER-620 & PBF Driver & 12000 & 0.84 & 2425 & rod & 560 & 18.3 & 102.8 & 0.56 \\
\hline $6 \mathbf{a}$ & INEL & CPP-IFSF & Ber-ll Triga & 254 & 0.24 & 21 & elem & 92 & 44 & 4 & 0.009 \\
\hline 6a & \multicolumn{2}{|c|}{ INEL Subtotal } & & 72844.3 & 32.932 & 8362 & & 37123.21 & & 1743.95 & 37.22792 \\
\hline $6 a$ & & & & & & & & & & 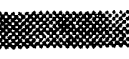 & 水滀 \\
\hline $6 \mathbf{a}$ & \multicolumn{2}{|c|}{ LANL Subtotal } & & 0 & 0 & 0 & & 0 & & 0 & 0 \\
\hline $6 a$ & ORNL & TSR & JASPER & 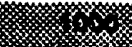 & 聯䊼 & 策 & units & 868 & 4.8 & 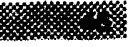 & 0.868 \\
\hline 6a & ORNL & $Y-12$ & HPRR & 级 & 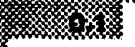 & 31 & pleces & 204 & 93 & 100 & 0.204 \\
\hline $6 a$ & ORNL & $Y-12$ & SNAP-10 & 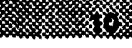 & 0.04 & 36 & rods & 4.0 & 93 & 4.6 & 0.005 \\
\hline $6 \mathbf{a}$ & \multicolumn{2}{|c|}{ OANL Subtotal } & & 1310 & 0.44 & 181 & & 1076.9 & & 230.6 & 1.077 \\
\hline $\mathbf{6 a}$ & SANDIA & ACPR & FREC & . & 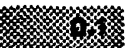 & 182 & elom & 9.8 & 20 & 级 & $\%$ \\
\hline $6 a$ & SANDIA & ACRR & ACRR & 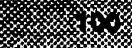 & 济 & 256 & olem & 26 & 35 & & 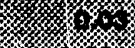 \\
\hline $6 a$ & SANDIA & ACRR & experiments & 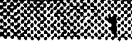 & 26 & & & 0.574 & & 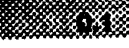 & 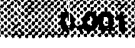 \\
\hline
\end{tabular}


SNF \& ERMM EIS Spent Nuclear Fuel Inventories Including Non-DOE locations - 6/1/ 1985

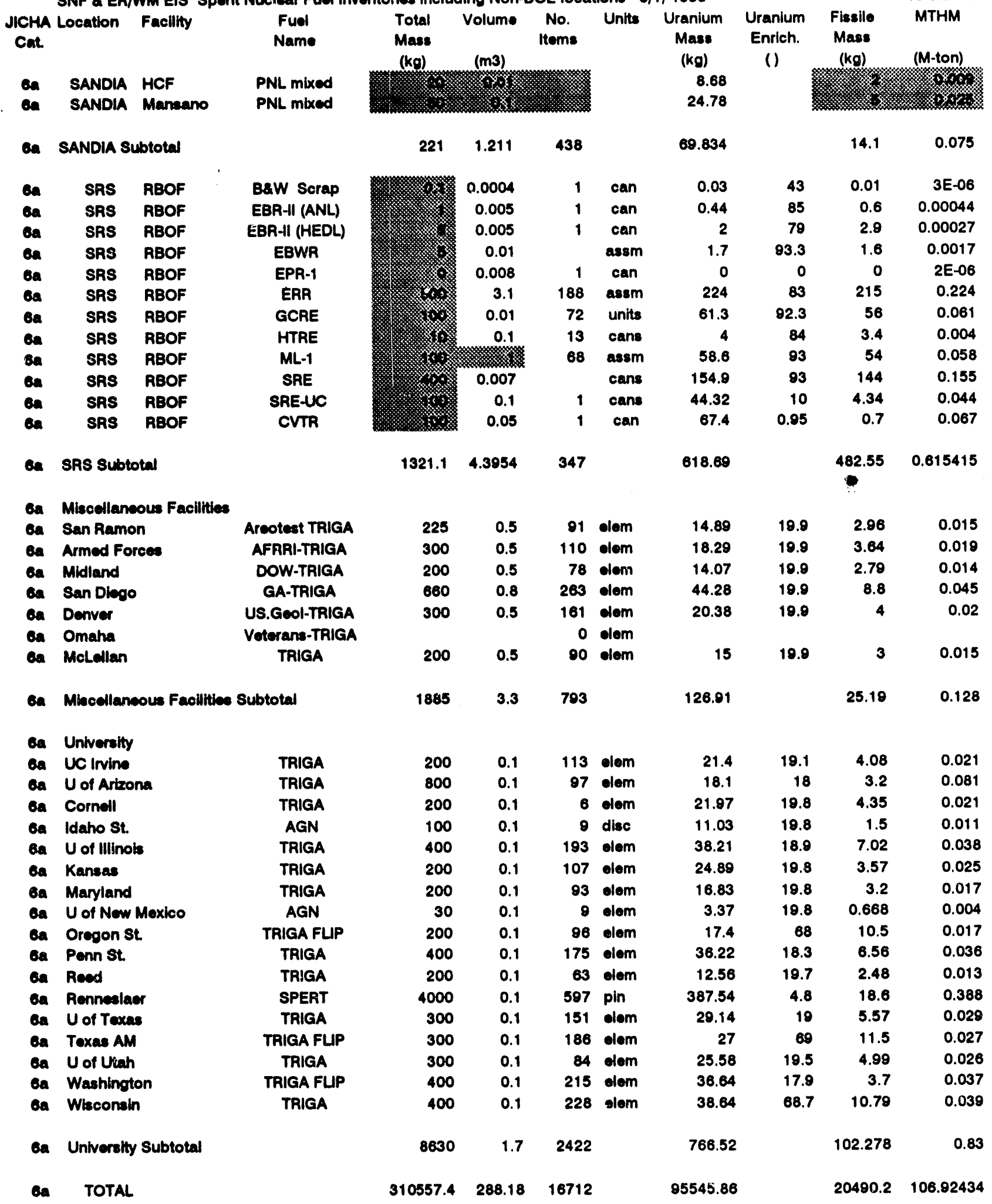

Experimental Zirconium Fuel

$\begin{array}{llllllr}\text { Bb ANL-W TREAT } & \text { TREAT } & 14.8 & 11 & 390 \text { assm } & 10 & 93 \\ \text { ob ANL-W Subtotal } & & 14.8 & 11 & 390 & 10 & 10\end{array}$


NF \& ERMM EIS Spent Nuclear Fuel Inventories Including Non-DOE locations - 6/1/ 1095

\begin{tabular}{|c|c|c|c|c|c|c|c|c|c|c|}
\hline $\begin{array}{l}\text { JICHA Location } \\
\text { Cat. }\end{array}$ & Facillty & $\begin{array}{l}\text { Fuel } \\
\text { Name }\end{array}$ & $\begin{array}{c}\text { Total } \\
\text { Mass } \\
\text { (kq) }\end{array}$ & $\begin{array}{c}\text { Volume } \\
\text { (m3) }\end{array}$ & $\begin{array}{l}\text { No. } \\
\text { Items }\end{array}$ & Unite & $\begin{array}{c}\text { Uranium } \\
\text { Mass } \\
\text { (ka) }\end{array}$ & $\begin{array}{l}\text { Uranium } \\
\text { Enrich. }\end{array}$ & $\begin{array}{l}\text { Fiasile } \\
\text { Mass }\end{array}$ & $\begin{array}{l}\text { MTHM } \\
\text { (M-ton) }\end{array}$ \\
\hline
\end{tabular}

\begin{tabular}{|c|c|c|c|c|c|c|c|c|c|c|c|}
\hline \multirow[t]{2}{*}{$6 b$} & \multirow[t]{2}{*}{ Hanford } & \multirow[t]{2}{*}{ T-plant } & \multicolumn{9}{|l|}{ Shiport PWR blanket } \\
\hline & & & Core 2 blanket & 38500 & 8.6 & 72 & assm & 15660 & 0.7 & 252 & 15.78 \\
\hline $6 b$ & \multicolumn{2}{|c|}{ Hanford Subtotal } & & 38500 & 9.6 & 72 & & 15880 & & 252 & 15.78 \\
\hline $6 b$ & INEL & CPP-668 & Fermi core I \& II & 4600 & 1.2 & 214 & can & 4000 & 25.4 & 1000 & 3.9 \\
\hline $6 b$ & INEL & CPP.666 & Shiport PWR C1-S4 & 2.9 & 0.18 & 4 & subass & 2 & 80.4 & 1.63 & 0.08 \\
\hline $\mathbf{b b}$ & INEL & CPP-666 & Shiport PWR C2-S1 & 6800 & 1.8 & 10 & clust & 210.1 & 60.1 & 129 & 0.219 \\
\hline $6 b$ & INEL & CPP-666 & Shiport PWR C2-S2 & 7100 & 1.8 & 20 & clust & 300.5 & 60.8 & 245 & 0.3 \\
\hline $\begin{array}{l}6 b \\
6 b\end{array}$ & $\begin{array}{l}\text { INEL } \\
\text { INEL }\end{array}$ & CPP.740 & Shiport LWBR & 84000 & 31.1 & 48 & can & 576 & 13 & 1100 & 42.57 \\
\hline 6b & INEL & MTR-603 & Belgian & 88.9 & 0.28 & 7 & canst & 62.4 & 4.7 & 3.2 & 2 \\
\hline $6 b$ & INEL & MTR-603 & PCM - TRA & 7.7 & 0.12 & 7 & canst & 5.4 & 28.6 & 1.55 & 0.028 \\
\hline $6 b$ & \multicolumn{2}{|c|}{ INEL Subtotal } & & 102599.5 & 36.47 & 310 & & 5165.4 & & 2480.38 & 47.157 \\
\hline 6b & NRF & ECF & Shiport PWR C1 & 25000 & 7 & 50 & olem & 500 & 70 & 350 & 0.5 \\
\hline $6 b$ & NRF & ECF & Shiport PWR C2 & 55000 & 16 & 110 & elem & 1100 & 70 & 770 & 1.1 \\
\hline $6 b$ & \multicolumn{2}{|c|}{ NRF Subtotal } & & 80000 & 23 & 160 & & 1600 & & 1120 & 1.6 \\
\hline $6 b$ & SRS & RBOF & EBWR & \% & 0.5 & 35 & assm & 918 & 0.23 & 2.1 & 0.818 \\
\hline $6 b$ & SRS & RBOF & EBWR & , & 3.0 & 280 & assom & 7438 & 0.00 & 74 & 7.44 \\
\hline $6 b$ & SRS & RBOF & EBWR & $3 \%$ & 0.86 & 60 & asem & 1600 & 6 & 96 & 1.6 \\
\hline $6 b$ & SRS & RBOF & EBWR & siv & 0.01 & 1 & can & 29 & 92 & 0.28 & 0.029 \\
\hline 6b & SRS & RBOF & HWCT HEU & s & 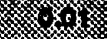 & 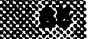 & units & 39.8 & 85 & 33.65 & 0.118 \\
\hline 6b & SAS & RBOF & HWCT LEU & 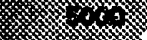 & 䊼 & 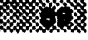 & units & 1824 & 0.7 & 13.2 & 1.8 \\
\hline $6 b$ & SRS & RBOF & ORNL (SIW) & 䊽 & 0.007 & 3 & cans & 0.18 & 93 & 0.17 & 0.00018 \\
\hline $6 b$ & SRS & ABOF & OANL mixed oxide & 桨 & 0.002 & 1 & $\operatorname{can}$ & 0.38 & 0.79 & 0.56 & 0.00038 \\
\hline $\mathbf{6 b}$ & SRS & RBOF & SPERT 3 & 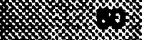 & 0.01 & 3 & can & 9.7 & 4.8 & 0.5 & 0.005 \\
\hline 6b & SRS & RBOF & shipingport & - & 0.02 & 1 & can & 16.4 & 0.14 & 0.24 & 0.016 \\
\hline 6b & \multicolumn{2}{|c|}{ SRS Subtotal } & & 120483 & 5.819 & 538 & & 11875.46 & & 220.7 & 11.92656 \\
\hline 6b & \multicolumn{2}{|l|}{ University } & & & & & & & & & \\
\hline $6 b$ & \multicolumn{2}{|l|}{ Buffalo } & pins & 2000 & 1 & 40 & elem & 403.19 & 5 & 27.81 & 0.493 \\
\hline $6 b$ & \multicolumn{2}{|c|}{ University Subtotal } & & 2000 & 1 & 40 & & 483.19 & 5 & 27.81 & 0.483 \\
\hline $6 b$ & TOTAL & & & 343597.3 & 86.889 & 1519 & & 34804.05 & & 4110.80 & 76.96656 \\
\hline
\end{tabular}

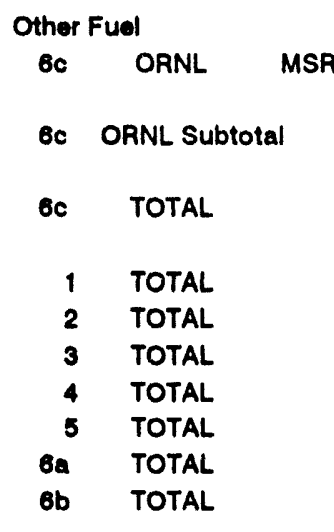

Other Fuel

\begin{tabular}{|c|c|}
\hline $6 c$ & OANL \\
\hline $6 c$ & ORNL Subtotal \\
\hline $6 c$ & TOTAL \\
\hline 1 & TOTAL \\
\hline 2 & TOTAL \\
\hline 3 & TOTAL \\
\hline 4 & TOTAL \\
\hline 5 & TOTAL \\
\hline $6 \mathbf{a}$ & TOTAL \\
\hline 6b & TOTAL \\
\hline
\end{tabular}

$\begin{array}{rrrr}12000 & 8.3 & 1 \text { core } & 36.95 \\ 12000 & 8.3 & 1 & 36.95 \\ 12000 & 8.3 & 1 & 36.95 \\ 539000 & 143 & 1088 & \\ 453024.6 & 187.58 & 15798 & 189481.6 \\ 2266437 & 205.25 & 8287 & 2099337 \\ 351000 & 292.72 & 3793 & 1256.6 \\ 230835.4 & 160.65 & 1537 & 164319.3 \\ 310557.4 & 288.18 & 16712 & 05545.86 \\ 343597.3 & 86.889 & 1519 & 34804.05\end{array}$

$\begin{array}{rrr}2.5 & 0.9 & 0.037 \\ & 0.9 & 0.037 \\ & & \\ 0.8 & 0.037 \\ & \\ 8770 & 9.947 \\ 8388.74 & 190.2112 \\ 30190.5 & 2103.43 \\ 839.4 & 27.603 \\ 4490.01 & 158.80685 \\ 20490.2 & 106.92434 \\ 4110.89 & 76.98656\end{array}$


SNF \& ERMM EIS Spent Nuclear Fud Inventories Including Non-DOE locations - 6/1/1995

\begin{tabular}{|c|c|c|c|c|c|c|c|c|c|c|c|}
\hline $\begin{array}{c}\text { JICH } \\
\text { Cat. }\end{array}$ & Location & Facillty & $\begin{array}{l}\text { Fuel } \\
\text { Name }\end{array}$ & $\begin{array}{c}\text { Total } \\
\text { Mass } \\
(\mathbf{k g})\end{array}$ & $\begin{array}{l}\text { Volume } \\
\text { (m3) }\end{array}$ & $\begin{array}{l}\text { No. } \\
\text { Itoms }\end{array}$ & Units & $\begin{array}{l}\text { Uranium } \\
\text { Mass } \\
\text { (kg) }\end{array}$ & $\begin{array}{l}\text { Uranium } \\
\text { Enrich. } \\
\text { () }\end{array}$ & $\begin{array}{l}\text { Fissile } \\
\text { Mass } \\
\text { (kg) }\end{array}$ & $\begin{array}{l}\text { MTHM } \\
\text { (Mton) }\end{array}$ \\
\hline ec & TOTAL & & & 12000 & 8.3 & 1 & & 38.95 & & 0.0 & 0.037 \\
\hline DOE & TOTAL & & & 4506452 & 1372.6 & 48736 & & 2594701 & & 78280.7 & 2673.9257 \\
\hline
\end{tabular}

1 INEL Subtotal

1 NAF subtotal

1 TOTAL

2 Brookhaven Subtotal

2 INEL Subtotal

2 LANL Subtotal

2 OANL Bubtotal

2 SANDIA Subtotal

2 SRS Subtotal

2 Non-DOE Subtotal

2 Univeralty Subtotal

2 TOTAL

3 TOTAL

- INEL subtotal

4 Pub. Ser. Subtotal

4 ORNL Subtotal

4 total

5 ANL-E Subtotal

5 Hanford Subtotal

5 INEL subtotal

5 Lynchburg Subtotal

5 ORNL subtotal

5 SRS Subtotal

5 WeatValloy subtotal

5 TOTAL

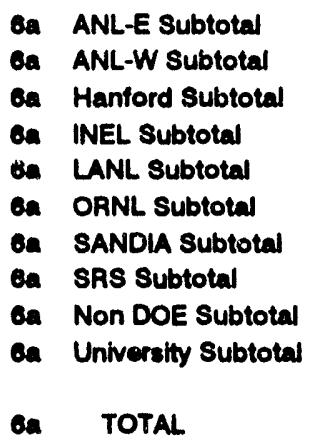

6b ANL-W Subtotal

bb Hanford Subtotal

\begin{tabular}{|c|c|c|c|c|c|c|c|}
\hline 350000 & 95 & 800 & & 6850 & & 6700 & 6.847 \\
\hline 189000 & 48 & 288 & & 3070 & & 3070 & 3.1 \\
\hline 530000 & 143 & 1088 & & 8920 & & 9770 & 8.947 \\
\hline 908 & 3.23 & 973 & & 251.88 & & 205.7 & 0.255 \\
\hline 14708.0 & 20.173 & 2281 & & 1863.7 & & 1378.92 & 1.881 \\
\hline 220 & 0.7 & 101 & & 21.25 & & 19.4 & 0.021 \\
\hline 9450.7 & 9.28 & 310 & 0 & 672.2 & & 629.6 & 0.6782 \\
\hline 830 & 0.5 & 43 & & 385 & & 370 & 0.37 \\
\hline 418220 & 150.7 & 11290 & & 183687 & & 5510.22 & 184.407 \\
\hline 280 & 0.3 & 218 & & 48 & & 44.2 & 0.048 \\
\hline 8310 & 2.7 & 574 & & 2552.64 & & 230.7 & 2.551 \\
\hline 453024.6 & 187.58 & 15799 & 0 & 189481.6 & 0 & 8388.74 & 190.2112 \\
\hline 2266437 & 205.25 & 8287 & & 2099337 & & 30190.5 & 2103.43 \\
\hline 161000 & 132.72 & 2347 & & 640.6 & & 506.4 & 11.6 \\
\hline 190000 & 160 & 1446 & & 616 & & 333 & 16 \\
\hline 552 & 0.5 & & & 3 & & 2 & 0.003 \\
\hline 181552 & 133.22 & 2347 & & 643.6 & & 508.4 & 11.603 \\
\hline 40 & 0 & 1 & & 19.5 & & 0.9 & 0.018 \\
\hline 3150 & 5.205 & 31 & & 2302 & & 67 & 2.32 \\
\hline 170059.4 & 145.4 & 800 & & 123647.2 & & 3014.67 & 123.6554 \\
\hline 60 & 0.11 & 15 & & 39.17 & & 0.32 & 0.044 \\
\hline 2010 & 2 & 445 & & 1222 & & 60.35 & 1.222 \\
\hline 3616 & 3.141 & 120 & & 11089.4 & & 271.774 & 4.54625 \\
\hline 42000 & 4.8 & 125 & & 26000 & & 1075 & 27 \\
\hline 230835.4 & 160.65 & 1537 & & 164318.3 & & 4400.01 & 158.80665 \\
\hline 70 & 0 & 4 & & 54 & & 46 & 0.06 \\
\hline 185020 & 203.04 & 3586 & & 47011 & & 17607 & 55.601 \\
\hline 59256 & 41.16 & 579 & & 8698.8 & & 229.58 & 11.31 \\
\hline 72844.3 & 32.932 & 8362 & & 37123.21 & & 1743.85 & 37.22792 \\
\hline 0 & 0 & 0 & & 0 & & 0 & 0 \\
\hline 1310 & 0.44 & 181 & & 1076.9 & & 239.6 & 1.077 \\
\hline 221 & 1.211 & 438 & & 69.834 & & 14.1 & 0.075 \\
\hline 1321.1 & 4.3954 & 347 & & 618.69 & & 482.55 & 0.615415 \\
\hline 1885 & 3.3 & 793 & & 126.91 & & 25.19 & 0.128 \\
\hline 8630 & 1.7 & 2422 & & 766.52 & & 102.278 & 0.83 \\
\hline 310557.4 & 288.18 & 16712 & 0 & 95545.86 & 0 & 20490.2 & 106.92434 \\
\hline
\end{tabular}

10
15660
10
252

0.01

15.78 
SNF \& ER/WM EIS Spent Nuclear Fuol Inventories Including Non-DOE locations - 6/1/ 1095

JICHA Location Facility
Cat.
6b INEL Subtotal
6b NRF Subtotal
6b SRS Subtotal

Total Volume No. Units Uranium

Mass

$(\mathbf{k g})$

102500.5

80000

120483

2000

343507.3

12000

12000

(m3)

$36.47 \quad 318$

Itoms

$23 \quad 160$

$5.810 \quad 538$

140

86.8891519

$8.3 \quad 1$

8.3

4506452

$1372.6 \quad 48736$
Mass

(kg)

5165.4

1600

11875.46

493.10

$0 \quad 34804.05$

36.85

36.95

2594701
13-Jul-94

MTHM

Uranium Fissile

() (kg)

2480.38

1120

220.7

27.81

4110.80

(M-ton)

47.137

1.6

11.82656

0.493

76.96856

$\begin{array}{ll}0.9 & 0.037 \\ 0.8 & 0.037\end{array}$

$78280.7 \quad 2673.9257$ 


\section{APPENDIX C. APPLICATION OF MPCs TO EACH DOE SNF CATEGORY}

The application of an MPC for each category of DOE SNF was compiled by the Team, based on the criteria presented in the report, and the evaluations are presented in the following (summarized in Table C-1):

\section{DOE SNF Category 1 - Naval Fuel}

The cladding is considered very stable compared to the other DOE SNF and commercial fuels, and is likely well characterized because of the high QA level of naval operations. The dimension and fuel composition information is well documented but classified as Confidential and would require clearance and need to know by the NRC and repository operating personnel. Some fuel may contain the control rods, and the resulting potential for designating the fuel as a hazardous waste needs to be resolved. The temperature limits are likely similar or higher than for commercial fuel. The fuel contains HEU, and the MPC would require fixed neutron poison material and possibly periodic verification of the material's stability for underwater loading and unloading and require a method for prevention of a criticality event during disposal according to 10 CFR $60.131(\mathrm{~b})(7)$. The fuel would require strict safeguards after closure of the repository. The waste package design requirements in 10 CFR 60.135 would probably be met. Under the existing fuel acceptance specifications, the naval fuel would be considered nonstandard fuel based on physical dimensions and uranium enrichment. Characterization for MPC use in disposal may consist of qualification of the detailed records of fuel use, which are classified, assuming that the waste acceptance requirements could be met. The high uranium enrichment and dimensions would make this fuel dissimilar to commercial fuel. The naval fuel is very stable and can be stored underwater for a long time, and thus there does not seem to be a driver for immediate placement into interim storage because of ES\&H vulnerabilities.

\section{DOE SNF Category 2 - Aluminum-Clad Fuel}

Most aluminum-clad DOE-owned fuel consists of cladding and fuel material that is not considered stable, and some of it has experienced severe corrosion and failure. Aluminum fuel does not appear to contain hazardous material. The maximum temperature in dry storage needs to be established and may be lower than for commercial fuel, possibly at $150^{\circ} \mathrm{C}$. The fuel contains HEU, and the MPC would require fixed neutron absorbing material for underwater loading and unloading and require a method for prevention of a criticality event during disposal according to 10 CFR 60.131(b)(7). The fuel would require strict safeguards after closure of the repository. The waste package design requirements in 10 CFR 60.135 may be met. Under the existing fuel-acceptance specifications, the aluminum fuel would be considered nonstandard fuel based on physical dimensions, cladding, cladding failure and uranium enrichment. There may be a short time to complete the characterization and/or stabilization to determine acceptability for repository disposal, and the canister may require re-opening to allow for the waste qualification activities before disposal. The generally high uranium enrichment and dimensions would make this fuel dissimilar to commercial fuel. The aluminum fuel is not very stable for underwater storage in most of the existing basins and may need to be placed in dry storage, assuming that this is successfully demonstrated, or further conditioned to eliminate the safety vulnerability. 
Table C-1. Evaluation by Criteria of MPC for Each DOE SNF Category. Rating of Each Criterion to an MPC is (H) High Acceptability, (M) Medium Acceptability, (L) Low Acceptability

DOE SNF Category:

\begin{tabular}{|l|l|l|l|l|l|l|l|l||}
\hline CRIT: & 1-Navy & 2-Al & 3-Hanf & 4-Graf & 5-Comm & 6a-SS & 6b-Zr & 6c-Oth \\
\hline $\begin{array}{l}\text { 1-Durab, } \\
\text { Dimens }\end{array}$ & H & L & M & H & H & H & H & L \\
\hline 2-Hazard & M & M & M & L & H & L & M & L \\
\hline $\begin{array}{l}\text { 3-Temp- } \\
\text { erature }\end{array}$ & H & L & H & H & H & $?$ & M & L \\
\hline 4-Critic & L & L & H & L & H & L & L & $?$ \\
\hline 5-SNM & L & L & H & L & H & L & L & $?$ \\
\hline $\begin{array}{l}\text { 6-Pckg } \\
\text { Reqmts }\end{array}$ & H & M & M & L & H & L & H & L \\
\hline $\begin{array}{l}\text { 7-Accep- } \\
\text { tability }\end{array}$ & H & L & M & L & H & L & M & L \\
\hline $\begin{array}{l}\text { 8-Simi- } \\
\text { larity }\end{array}$ & L & L & M & L & H & L & M & L \\
\hline 9-Timing & H & L & M & H & H & M & L & L \\
\hline
\end{tabular}

a. After stabilization to achieve minimum acceptable criteria for interim storage because this material is not suitable for dry storage in its present form.

b. Assuming intact commercial fuel; non-intact fuel may require stabilization to meet acceptable levels.

c. Shippingport PWR Core II fuel is expected to meet all criteria. 


\section{DOE SNF Category 3 - Hanford N-Reactor and Single Pass Reactor Fuel}

The zircaloy cladding, which is also present in commercial fuel, has a significantly higher failure rate than commercial fuel. The cladding failure has resulted in undesired water reaction with the metal fuel for fuels not sealed in the N-Reactor canisters. Thus, fuel stabilization will be required prior to acceptance in a repository and is currently under evaluation. The fuel is potentially pyrophoric and gas generating and may be designated as hazardous waste.Temperature limits would have to be established for the final stabilized form. The plutonium level may not require some fixed neutron absorber material, unless the fuel configuration is changed significantly from the current N-Reactor canisters. The safeguards requirements should be similar to commercial fuel after closure of the repository, although many of the fuels may not be self-protecting after 50 years. Under the existing fuel acceptance specifications, the fuel would be considered nonstandard based on physical dimensions and cladding failure, and it may not meet waste package design requirements 10 CFR 60.135 without stabilization. The uranium enrichment of up to $1.25 \%$ is lower than in commercial fuel, but the fuel has different dimensions than commercial fuel is composed of uranium metal, rather than uranium dioxide. The fuel and existing storage canisters are stable in the existing basins but may need to be placed in dry storage after stabilization, assuming that this is successfully demonstrated. There may be a short time to complete the characterization and stabilization, which will likely be required to determine acceptability for repository disposal, and the canister may require re-opening before disposal.

\section{DOE SNF Category 4 - Graphite Fuel}

Although the fuel cladding is considered stable, the presence of carbides and potentially flammable graphite may require additional conditioning or stabilization prior to repository acceptance. The carbide and graphite may result in designating the fuel as a hazardous waste. The temperature limits are likely similar or higher than for commercial fuel. The fuel contains HEU, and the MPC would require fixed neutron poison material during handling and interim storage and require a method for prevention of a criticality event during disposal according to 10 CFR $60.131(\mathrm{~b})(7)$. The fuel would require strict safeguards after closure of the repository. The waste package design requirements in 10 CFR 60.135 may not be met because of the flammable and potentially chemically reactive nature. Under the existing fuel acceptance specifications, the graphite fuel would be considered nonstandard based on composition, dimensions and uranium enrichment. The graphite and carbide composition, high uranium enrichment and dimensions would make this fuel dissimilar to commercial fuel. The graphite fuel has been in dry storage for nearly $20 \mathrm{yr}$ in a facility which may have a seismic deficiency vulnerability, and it may require placement into different interim storage. As a result, there may not be sufficient time for characterization for MPC use in disposal.

\section{DOE SNF Category 5 - Commercial Fuel}

DOE-owned commercial fuels with stable cladding have similar dimensions as other commercial fuel owned by utilities. There may be little potential for designation as a hazardous waste, except for TMI fuel rubble which contains pieces of control rods, which might be hazardous. For intact elements, the temperature limits are the same as other commercial fuel. The plutonium level may require some fixed neutron poison material, but 
presumably not require the strict safeguards of HEU after repository closure. The enrichment, composition, and characterization will likely meet the waste acceptance requirements as with other commercial fuel, assuming that the operating records are comparable. Waste package design requirements under 10 CFR 60.135 would presumably be met for intact fuel elements. Commercial fuel pieces may require stabilization before placement in an MPC. Some DOE commercial fuel may require removal from existing facilities in the near future; for example, LWR fuel in the Hanford 324 building may have to be removed in the next two years; West Valley fuel shipments are mandated by DOE agreements with the State of New York; and commercial fuel will need to be removed from the TAN storage basin.

\section{DOE SNF Category 6a - Experimental Stainless-Steel Fuel}

The durability of stainless-steel fuels are comparable to commercial fuel, although some cladding leaks have been observed. The components, sodium, carbides and hydrides, may result in a hazardous waste classification. The temperature limits need to be established. The MPC for high-enriched fuels would require fixed neutron material during handling and interim storage and require a method for prevention of a criticality event during disposal according to 10 CFR 60.131 (b)(7). Strict safeguards would be required after closure of the repository. Waste package design requirements may not be met for some of the stainlesssteel clad fuels due to the potentially hazardous components. The fuel may require additional characterization and possibly stabilization to determine acceptability for repository disposal. Most of the stainless-steel experimental fuels are dissimilar to commercial fuel in plutonium content or high uranium enrichment as well as different cladding material. Casks are being designed for FFTF fuels with fuel placement projected for FY 1996, subject to the outcome of the Environmental Assessment (EA). Stainless-steel clad fuels will have to be removed from the basins in CPP-603 and -666 to dry storage because of potential ES\&H vulnerabilities from encapsulated sodium metal.

\section{DOE SNF Category 6b - Experimental Zirconium Fuel}

Some of the experimental zirconium fuel has a similar durability and dimensions as commercial fuel. There is probably no potential for designation as a hazardous waste. The temperature limits need to be determined. The MPC for high-enriched $\mathrm{Zr}$-clad fuels would require fixed neutron poison material during handling and interim storage and require a method for prevention of a criticality event during disposal according to 10 CFR 60.131(b)(7). Strict safeguards would be required after closure of the repository. The waste package design requirements 10 CFR 60.135 are expected to be met. Some fuel may require additional characterization prior to acceptance for repository disposal. Some of the fuels have similar fuel material and enrichment as commercial fuel, such as the Shippingport PWR Core II. Fuels stored in the PBF basin will need to be transferred to CPP during 1996-8. 


\section{DOE SNE Category 6c - Other Fuel}

This fuel includes mainly molten salt reactor fuels, consisting of sodium, calcium and uranium fluoride salts. It is expected to contain possible RCRA hazardous materials and the fuel has a potential for being designated as a hazardous waste. Temperature limitations, criticality concerns, and safeguards issues need to be established. The fuel must be conditioned and stabilized to meet waste package requirements. It would likely require additional stabilization and characterization prior to acceptance for repository disposal. There are no similarities with respect to durability, cladding and compositional characteristics with respect to commercial fuel. Timing for removal has to be determined. 

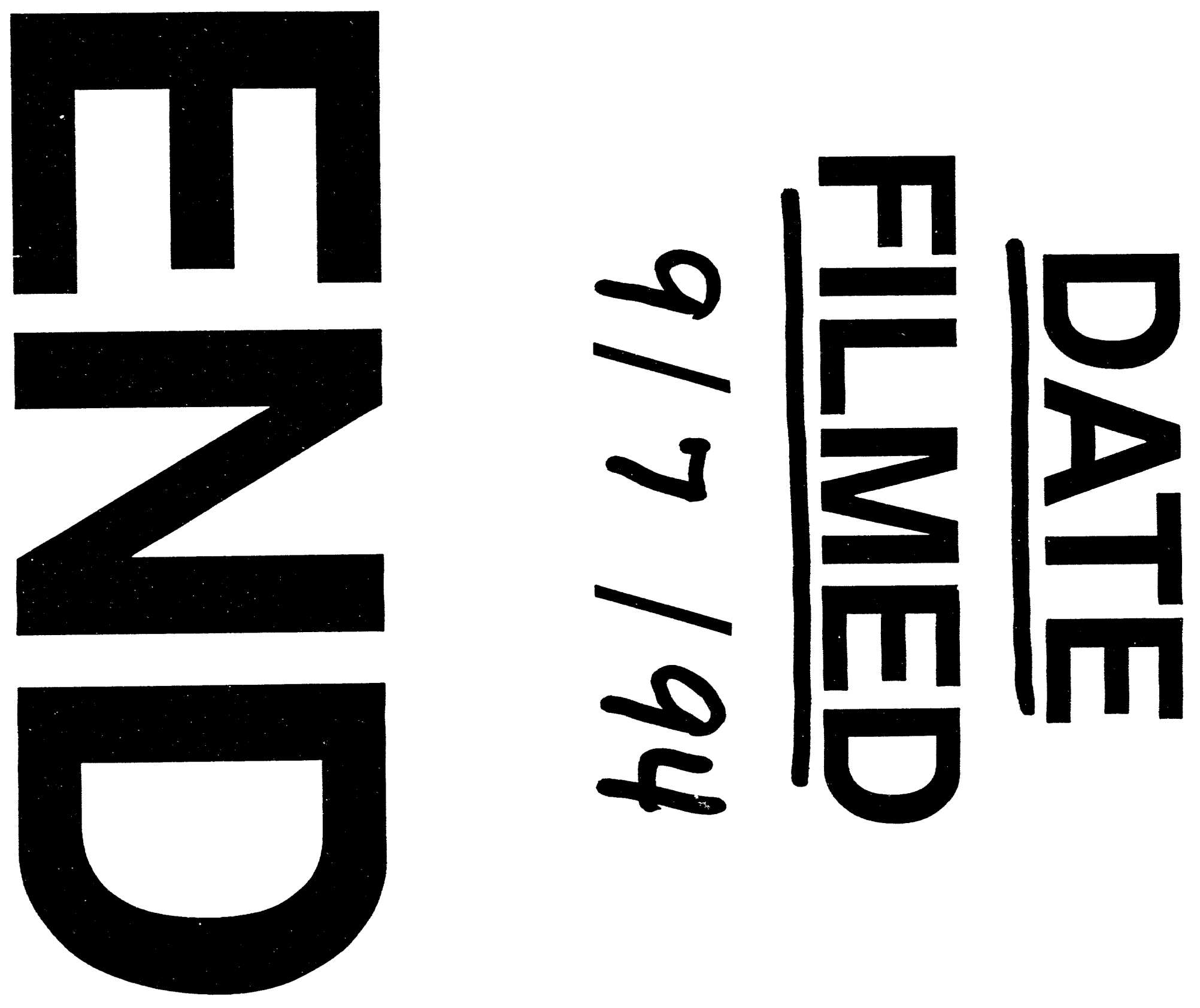
